\title{
MANUFACTURING EVIDENCE FOR TRIAL: THE PREJUDICIAL IMPLICATIONS OF VIDEOTAPED CRIME SCENE REENACTMENTS
}

\author{
DAVID B. HENNES $\dagger$
}

\section{INTRODUCTION}

When the Mitchell brothers partied, they partied hard. The brothers, Artie and Jim, were renowned for their pornographic film and theater empire. ${ }^{1}$ Although the Mitchells were notorious for their carousing together, Jim had become increasingly distraught over his brother's drug and alcohol habit, worried that it was threatening their extensive business dealings. ${ }^{2}$ Thus, when pornking Artie Mitchell's bullet-ridden body was found in the bedroom of his California home, it came as little surprise to those who knew them that Artie's older brother Jim was arrested near Artie's home while trying to draw a concealed rifle on the responding officer. ${ }^{3}$

The events that actually transpired inside the Mitchell house that night remain a mystery. Jim claimed that the killing was accidental ${ }^{4}$ and that he could not recall any of the events surrounding the shooting. ${ }^{5}$ Armed with circumstantial evidence, ballistics reports,

+ B.A. 1991, University of Michigan; J.D. Candidate 1995, University of Pennsylvania. I am grateful to my Law Review colleagues for all of their assistance in seeing this project through to its completion, especially those in the Comments Office. This Comment is dedicated with love to my parents, Dale Freeman and Peter Hennes. If not for their encouragement, support, and caring, this would not have been possible.

1 The Mitchell brothers' success was built around "an empire of adult theaters for live sex shows and films." U.S. Porn King Sentenced for Killing Brother, The Reuter Library Report, Apr. 24, 1992, available in LEXIS, News Library, Reuwld File. Jim and Artie Mitchell were well known prior to the murder because of their "flamboyant exploitation of flesh [that] made them rich while they were still in their 20s." Garry Abrams, Of Flesh and Blood: Another Scandal-This Time, Homicide-Shakes the Mitchell Brothers' X-Rated Empire, L.A. TIMES, May 5, 1991, at E1.

${ }^{2}$ Prosecutors claimed that Artie Mitchell was "in his last months caught in a spiral of drug and alcohol abuse that . . . stimulated increasingly erratic behavior, disrupted the business and provoked the killing." Abrams, supra note 1, at El.

${ }^{3}$ See id. at E18.

See Diane Curtis, Mitchell Trial Judge Approves Re-creating Slaying on Video, S.F. CHRON., Jan. 28, 1992, at A1 ("Defense attorneys do not deny that Jim Mitchell fired the shots that killed his brother, but they say the killing was accidental and not murder.").

${ }^{5}$ See Diane Curtis, Jim Mitchell Testifies About Fatal Shooting, S.F. CHRON., Feb. 11. 1992, at A13 [hereinafter Curtis, Mitchell Testifies] ("[P]orn czar Jim Mitchell . . . gave his first public accounting of the slaying of his brother Artie, testifying at his murder 
and the opinions of the Mitchells' friends, prosecutors set out to piece together the events leading to the death of one of California's most notorious citizens. ${ }^{6}$

At about the same time that Jim Mitchell took the life of his brother and business partner, another fatal incident involving conflicting factual accounts occurred on the opposite side of the country. Officer Gary Spath of the Teaneck, New Jersey, police department was called to the William Cullen Bryant School to investigate reports of a youth brandishing a gun. ${ }^{7}$ Upon arriving at the scene, Officer Spath encountered a sixteen-year-old black youth named Phillip Pannell. ${ }^{8}$

The subsequent confrontation between Spath and Pannell ignited a heated conflict in the previously harmonious, racially diverse community. ${ }^{9}$ Neither side disputed the events leading up to the fatal encounter. Following Spath's arrival on the scene, a short chase on foot ensued. ${ }^{10}$ Spath then fired two shots, one of

trial that he remembers almost nothing about the shooting of his younger sibling and partner."). Mitchell later stated that "he did not remember the shooting but had gone to his brother's home to intervene in Artie's demonic and increasingly dangerous alcoholism." Diane Curtis, Porn King Jim Mitchell Gets 6-Year Sentence: He Is Free Pending Appeal in Brother's Slaying, S.F. CHRON., Apr. 25, 1992, at Al [hereinafter Curtis, Porn King].

${ }^{6}$ See Richard Barbieri, Mitchell Prosecutors to Present Last 56 Seconds of Porn King's Life: Testimony at Jim Mitchell Fratricide Trial Will Feature Shot-by-Shot Recreation, THE RECORDER, Oct. 17, 1991, at 1 . Jim Mitchell was eventually convicted of voluntary manslaughter and sentenced to six years in prison. See Curtis, Porn King, supra note 5 , at Al.

7 See Robert Hanley, Officer Acquitted in Teaneck Killing, N.Y. TIMES, Feb. 12, 1992, at B7; Tracy Schroth, Teaneck Drama Opens: Some Props, No Guns, 130 N.J. L.J. 153, 153 (1992).

${ }^{8}$ See Hanley, supra note 7, at B7; Schroth, supra note 7, at 153. Defense attorney Robert Galantucci depicted Pannell, the victim of the shooting, as a "junior criminal, already on probation and a member of a street gang." Melinda Henneberger, Science us. Emotion: Trial of Teaneck Police Officer Opens, N.Y. NEwSDAY, Jan. 16, 1992, at 21.

${ }^{9}$ See Ronald J. Fleury, Skirmish of the Experts Bedraggles Teaneck Case, 129 N.J. L.J. 269, 269 (1991) ("In the headlines, the manslaughter prosecution of Teaneck policeman Gary Spath is about race, police brutality, and an ethnic protest that evoked shades of Bensonhurst and Howard Beach [New York communities torn by racial violence] in a quiet Bergen County suburb."); Hanley, supra note 7, at B12 (noting that "the night of unrest tarnished Teaneck's image as a racially harmonious town"); Rorie Sherman, Moving Graphics: Computer Animation Enters Criminal Cases, NAT'L L.J., Apr. 6, 1992, at 1, 32 ("The killing garnered national attention because it sparked race riots in Teaneck, N.J., a town previously thought a model of harmonious integration.").

${ }^{10}$ See Schroth, supra note 7, at 153 (stating that witnesses at the scene noticed that "[w]hen Pannell ran from the group, Spath and another officer ... took chase with their guns drawn"). 
which struck Pannell in the back, fatally wounding him. ${ }^{11}$ Upon subsequent investigation, the loaded handgun that precipitated the deadly engagement was found in Pannell's pocket. ${ }^{12}$

In the aftermath of the shooting, the accounts of what prompted Spath's decision to fire at Pannell sharply diverged. Prosecutors indicted Spath on charges of reckless manslaughter, claiming that Pannell had his hands raised in surrender when the fatal shot was fired. ${ }^{\text {is }}$ Spath denied the charges, and countered that he fired in self-defense, believing that Pannell was reaching for the concealed firearm while "turning toward him in a threatening gesture."14

As so often happens in criminal trials, the prosecution and defense in both People v. Mitchell ${ }^{15}$ and New Jersey v. Spath ${ }^{16}$ presented conflicting versions describing the factual scenario leading up to the fatal events. ${ }^{17}$ In order to obtain a conviction, prosecutors in both cases were faced with the daunting prospect of piecing together the exact circumstances of the killings based on conflicting evidence and testimony. ${ }^{18}$ To accomplish this task and to prove guilt beyond a reasonable doubt, ${ }^{19}$ prosecutors in both cases

"See Hanley, supra note 7, at B7.

${ }^{12}$ See Tracy Schroth, State Rebuts Defense in Teaneck Cop Case, 128 N.J. L.J. 1140, 1140 (1991).

13 See id.

${ }^{14}$ Robert Hanley, Science Cannot Duplicate Victim's Acts, Expert Says, N.Y. TIMES, Feb. 5, 1992, at B4.

${ }^{15}$ No. 12462 (Cal. Super. Ct. Marin County indictment filed Sept. 17, 1991).

${ }^{16}$ No. SGJ263908 (N.J. Super. Ct. Crim. Div. filed Dec. 5, 1990).

${ }^{17}$ In Mitchell's trial, the prosecution argued that Jim Mitchell murdered his brother without provocation, alleging that he was upset that his younger brother's drug and alcohol abuse was affecting their business partnership. See Abrams, supra note 1 , at E18. In contrast, Jim averred that Artie provoked the exchange by confronting Jim with a bottle. See Curtis, supra note 4, at A1.

In Spath's trial, the prosecution attempted to prove that the victim had his back turned to the officer and alleged that Spath had fired recklessly and without provocation. See Schroth, supra note 7, at 153. The defense, however, countered that the victim was turning toward Spath while reaching for the concealed weapon that originally drew the officer to the scene. See Hanley, supra note 14, at B4.

${ }^{18}$ Spath elected to testify on his own behalf and forego his Fifth Amendment privilege against self-incrimination. See Hanley, supra note 7, at B7. Spath's testimony, in direct contradiction to claims of the prosecution, highlighted the conflict between the stories. Although Jim Mitchell testified, his testimony centered around his inability to recall the events of the evening. See Curtis, Mitchell Testifies, supra note 5, at A13.

${ }^{19}$ See In re Winship, 397 U.S. 358, 364 (1970) (holding that the U.S. Constitution requires proof beyond a reasonable doubt in criminal trials). 
commissioned the production of videotaped reenactments ${ }^{20}$ to illustrate their version of the facts. ${ }^{21}$

Prior to the admission of the videotaped reenactments in the Mitchell and Spath cases, the use of such reenactments in criminal trials was largely rejected by state courts. ${ }^{22}$ The Mitchell and Spath evidentiary rulings, which granted the prosecutions' requests to present the reenactments to the jury, ${ }^{23}$ signify the beginnings of a significant shift in judicial philosophy concerning the admission of videotaped crime scene reenactments. ${ }^{24}$ In light of the recent

${ }^{20}$ Videotaped reenactments are also known as video "reconstructions" or video "re-creations." Throughout this Comment, the term "reenactment" will refer to any form of videotaped re-creation of prior criminal acts.

In constructing a crime scene reenactment, prosecutors and experts are "purport[ing] to show what actually happened, using data derived from the ... investigation." Michael J. Henke, Admissibility of Computer-Generated Animated Reconstructions and Simulations, 35 TRIAL LAW. GUIDE 434, 436 (1991). A reenactment differs from a simulation because the latter is an "artificially created extrapolation" that "takes known factual data ... and 'continues the event beyond [its] stated mathematical or factual basis' to show either what 'would have happened' under different conditions or "alternate theories of [how the event occurred]." Id. (footnote omitted). Although the reenactment is more speculative than the simulation, the two are similar to some extent because both rely "on inductive reasoning, hypothesis, and scientific assumptions." Id. at 437 . Thus, the prosecutor and expert utilize physical evidence, testimony, hypothesis, and experience to piece together the intricate details of exactly how a crime occurred for presentation to the trier of fact in the form of a videotaped reenactment.

${ }^{21}$ See Curtis, supra note 4, at Al (stating that the judge in Spath's trial allowed a re-creation of the shooting to be shown to the jury); Robert Hanley, Re-enactment Tape Is Allowed in Officer's Trial, N.Y. TIMES, Jan. 15, 1992, at BI ("The judge . . . accepted into evidence an unusual videotaped re-enactment.").

${ }^{22}$ See, e.g., State v. Trahan, 543 So. 2d 984, 997 (La. Ct. App. 1989) ("[The videotaped reenactment] was inadmissible because the reconstruction did not accurately depict the condition or the position of the parties."), overruled on other grounds by State v. Simpson, 551 So. 2d 1303, 1304 (La. 1989), but affd, 576 So. 2d 1 (La. 1990); State v. Hopperstad, 367 N.W.2d 546, 549 (Minn. Ct. App. 1985) (overruling the trial court's admission of a videotaped reenactment depicting the events surrounding defendant's arrest); State v. Caudill, 789 S.W.2d 213, 216 (Mo. Ct. App. 1990) ("A videotape reenactment of a crime . . . where the victim reenacts the crime with a third party playing the role of the defendant, should be and is hereby declared inadmissible in Missouri."); Lopez v. State, 651 S.W.2d 413, 416 (Tex. Ct. App. 1983) ("We find that any staged, re-enacted criminal acts . . . involving human beings are impossible to duplicate in every minute detail and are therefore inherently dangerous, offer little in substance and the impact of re-enactments is too highly prejudicial to insure the State or the defendant a fair trial.").

${ }^{23}$ Although independent of one another, the admission of the reenactments in both trials occurred within days of each other. The reenactment in Spath's trial was accepted by the judge for presentation to the jury on January 14, 1992. See Hanley, supra note 21, at B1. The use of the reenactment in Mitchell's trial was approved by the court on January 27, 1992. See Curtis, supra note 4, at A1.

${ }^{24}$ Many within the legal community have criticized this shift. See, e.g., Curtis, supra 
judicial acceptance of reenactments in these two nationally publicized cases and the rapid development rate of computer and video technology, one commentator predicted that " [c]riminal trials are on the verge of a technological revolution that will allow lawyers to transform experts' dry, verbal testimony into dynamic, TV-like shows that can mentally transport jurors to crime scenes and play out for them an advocate's version of events. ${ }^{25}$

This Comment argues that the use of videotaped reenactments of crime scenes prejudices the rights of criminal defendants under the balancing test of Rule 403 of the Federal Rules of Evidence by compelling the trier of fact to commit inferential error. ${ }^{26}$ Though relatively instinctive in nature, the logic utilized by those courts that have rejected the use of videotaped reenactments ${ }^{27}$ is correct in assessing the prejudicial nature and effect of reenactments on juror deliberations in criminal trials. The admission of videotaped reenactments by the trial courts in Spath and Mitchell, therefore, should be treated as anomalies in judicial reasoning by future courts confronting the issue. Part I of this Comment articulates the differences between demonstrative and real evidence and details the treatment various forms of videotaped evidence have received in both civil and criminal trials. Part I concludes by briefly outlining the purported advantages of using demonstrative evidence at trial.

Part II begins by examining the use of videotaped reenactments in civil trials. This Part then categorizes the reasoning employed by courts when confronted with a civil reenactment and the potential dangers that this form of evidence presents to litigants. The first half of Part II sets forth several generalizations regarding the use and acceptance of videotaped evidence at trial and shows how, as

note 4, at A1 (quoting Professor Ellen Kreitzberg as "shocked' that such a re-creation might be admitted at a criminal trial" and saying that " $[\mathrm{t}] \mathrm{his}$ kind of technology . . . is designed to appeal to those kinds of things that shouldn't be admissible' ); Sherman, supra note 9, at 32 ("The unknown psychological impact [of videotaped reenactments] worries some lawyers."); Rorie Sherman, Psychological Impact Is Unclear, NAT'L L.J., Apr. 6, 1992, at 33, 33 (noting that attorneys were concerned that when viewing the reenactments "[j]urors might be unduly influenced; extraneous information might accidentally trigger juror biases; [and that] the material might contain subliminal messages").

${ }^{25}$ Sherman, supra note 9 , at 1 .

${ }^{26}$ Rule 403 provides that evidence, " [a]lthough relevant, . . . may be excluded if its probative value is substantially outweighed by the danger of unfair prejudice, confusion of the issues, or misleading the jury, or by considerations of undue delay, waste of time, or needless presentation of cumulative evidence." FED. R. EVID. 403. For a further discussion of Rule 403, see infra notes 209-38 and accompanying text.

${ }^{27}$ See supra note 22 (discussing four state courts that have rejected such evidence). 
compared to other forms of videotaped evidence, civil and criminal reenactments have been subject to a heightened level of judicial scrutiny. The remainder of this Part examines in detail how courts have treated reenactments in criminal trials and suggests that advances in computer and video technology make it increasingly likely that this form of evidence will continue to appear with greater frequency at trial in the future. Finally, Part II outlines the logic that various state courts have employed when confronted with crime scene reenactments in an attempt to categorize the dominant rationale driving their exclusion.

Part III discusses Rule 403 of the Federal Rules of Evidence and presents the evidentiary basis for excluding prejudicial evidence under the Federal Rules. This Part articulates the philosophy underlying the Federal Rules and examines the impact of decisions under the Federal Rules on the "law" of evidence. Part III then turns specifically to Rule 403 and attempts to craft a definition of "unfair prejudice," concluding that unfair prejudice is best defined as occurring when evidence is employed that causes the trier of fact to commit inferential error. Through an examination of judgmental heuristics, this Part then attempts to determine which cognitive processes subsequently cause inferential error. The cognitive utilization of judgmental heuristics-both the availability heuristic and the representative heuristic-is then applied to the viewing of a videotaped reenactment by the trier of fact. The Comment concludes that the prosecution's use of videotaped crime scene reenactments unfairly prejudices criminal defendants.

\section{Demonstrative Evidence AND THE USE of Video AT TRIAL}

\section{A. Demonstrative Versus Real Evidence}

Demonstrative evidence, defined as "any display that is principally used to illustrate or explain other testimonial, documentary, or real proof, ${ }^{28}$ plays a central and valuable role in both civil $^{29}$ and

${ }^{28}$ Robert D. Brain \& Daniel J. Broderick, The Derivative Relevance of Demonstrative Evidence: Charting Its Proper Evidentiary Status, 25 U.C. DAvIS L. REv. 957, 968-69, (1992) (footnotes omitted). Brain and Broderick note that demonstrative evidence "is, in short, a visual (or other sensory) aid." Id. at 969.

Black's Law Dictionary defines demonstrative evidence as "[ $t]$ hat evidence addressed directly to the senses without intervention of testimony." BLACK's LAW DICTIONARY 432 (6th ed. 1990). One author considers demonstrative evidence to be that which "re-creates events for a decisionmaker without intervening recitation other than to authenticate the evidence." RICHARD A. GIVENS, DEMONSTRATIVE EVIDENCE 
criminal trials. ${ }^{30}$ It comes in many forms and types, varying from mundane documentary evidence to visually stimulating demonstrations. ${ }^{31}$ Classifying all evidence that is considered "visual" as demonstrative, however, can be misleading. ${ }^{32}$

A further distinction must be made between purely demonstrative evidence and real evidence. Real evidence "provides the trier of fact with an opportunity to draw a relevant firsthand sense impression" and "involves production of an object which usually . . . had a direct or indirect part in the incident. ${ }^{33}$ Purely demonstrative evidence, on the other hand, is derivative in nature, as it "only illustrates or clarifies other substantive evidence. ${ }^{n 4}$ Thus, real

$\S 1.01$, at 3 (1989).

${ }^{29}$ See infra notes $38-45$ and accompanying text (documenting the use of videotaped evidence in civil trials); see also Roland v. Langlois, 945 F.2d 956, 963 (7th Cir. 1991) (holding that the lower court did not err in the admission of a life-size model in an action brought by a carnival patron injured by an amusement ride).

${ }^{30}$ See infra notes 46-53 and accompanying text (documenting uses of videotaped evidence in criminal trials); see also United States v. Willis, 759 F.2d 1486, 1501 (11th Cir. 1985) (holding that the lower court did not err in allowing "the playing before the jury of a silent videotape showing police executing [a] search warrant $t^{n}$ ).

${ }^{31}$ See GIvENS, supra note $28, \S 2.01$, at 28-29. Givens notes that demonstrative evidence can come in the form of "illustration charts, maps, photographs, audio and videotapes, demonstrations, models, and experiments." Id. at 28 (footnote omitted). The reenactments produced for the Spath and Mitchell trials would be considered "visually stimulating" because they demonstrated the events in dispute with color, lights, and movement. See infra part II.B.4; see also infra part III.E (discussing the cognitive impact of demonstrative evidence).

${ }_{32}$ See Brain \& Broderick, supra note 28, at $981 \mathrm{n} .74$ ("It is a failure to appreciate th[e] distinction [between real and demonstrative evidence] that has caused much of the present day confusion surrounding demonstrative evidence. That is, instead of acknowledging demonstrative evidence as its own branch of evidence, commentators will often try to analyze it as a special application of real evidence.").

${ }^{3 s}$ Michael H. Graham, Evidence and Trial Advocacy Workshop: Relevancy and Exclusion of Relevant Evidence-Real Evidence, 18 CRIM. L. BULL. 241, 241 (1982). Graham points out that real evidence may include "[m]urder weapons, narcotic substances, and articles of clothing." Id. Thus, real evidence is that which is often referred to as the "smoking gun" or the "bloody towel."

Real evidence must also meet a stricter evidentiary standard under the Federal Rules of Evidence to be admissible. It must be authenticated according to Rule 901, meet basic relevancy standards as outlined in Rule 401, and must not be prejudicial as defined by Rule 403. See FED. R. Evid. 401, 403, 901.

${ }^{34}$ Brain \& Broderick, supra note 28, at 973 (noting that demonstrative evidence is "entirely derivative of other evidence, and its only value at trial is when it is linked to other substantive proof"). Graham explains that demonstrative evidence has "no probative value in itself" and that "[s]uch evidence serves merely as a visual aid to the jury in comprehending the verbal testimony of a witness or other evidence." Graham, supra note 33, at 242; see also Carson v. Polley, 689 F.2d 562, 579 (5th Cir. 1982) ("Illustrative evidence is admitted solely to help the witness explain his or her testimony. Illustrative evidence has no probative force beyond that which is lent to 
evidence, possessing independent probative value, ${ }^{35}$ may be carried with the jury into deliberations. Demonstrative evidence, with no independent probative value, may not enter the jury room.

Crime scene reenactments, which are postlitigation creations, are purely demonstrative evidence, carrying no independent probative value. ${ }^{36}$ One commentator points out that the evidential weight of demonstrative evidence is weak because it is "selfconscious evidence that comes into existence after the event, through the self-help of the litigants, their lawyers, and their graphics consultants. ${ }^{\text {37 }}$

\section{B. Videotaped Evidence as Demonstrative Evidence}

Many types of demonstrative evidence have gained wide acceptance in the courtroom. ${ }^{38}$ Videotaped evidence, a form of demonstrative evidence, has received significant acceptance in many forms as well. ${ }^{39}$ In civil trials, videotaped evidence has been used to demonstrate scientific experiments or principles, ${ }^{40}$ to depict the scene of an area in dispute, ${ }^{41}$ to portray a "day in the life" of an

it by the credibility of the witness whose testimony it is used to explain.").

${ }^{35}$ See infra part III.C.2 (discussing probative value under the Federal Rules of Evidence).

${ }^{36}$ See Brain \& Broderick, supra note 28, at 965 (noting that demonstrative evidence "has no independent effect on the determination of the existence of a fact of consequence, other than its helpfulness as an illustrative aid to another, independently relevant piece of substantive evidence").

${ }^{37}$ Ashley S. Lipson, "Real" Real Evidence, LITIG., Fall 1992, at 29, 30.

${ }^{38}$ See Brain \& Broderick, supra note 28, at 962 ( ${ }^{\circ}$ Contemporary jurists and lawyers continue to share the historical vision that demonstrative proof can be used at trial as a matter or right, subject only to the discretion of the trial judge to preclude individual exhibits that are unfairly prejudicial, inaccurate, incomplete, or cumulative.").

${ }^{39}$ See Gregory P. Joseph, Videotape Evidence in the Courts-1985, 26 S. TEX. L.J. 453, 453 (1985). Joseph, a current member of the Supreme Court's Advisory Committee on the Federal Rules of Evidence, notes that the "potential evidentiary applications of videotape are extensive" and that the "prevailing trend of the decisions clearly favors admissibility." Id.

${ }^{40}$ Videotapes of this kind are often used to clarify an expert witness's testimony or to explain the functioning of a piece of machinery. See id. at 461; see also Brandt v. French, 638 F.2d 209, 212 (10th Cir. 1981) (holding that the lower court did not err in allowing a film used to "show mechanical principles relative to ... how a motorcycle leans when it turns"); Young v. Illinois Cent. Gulf R.R., 618 F.2d 332, 33738 (5th Cir. 1980) (holding that lower court did not err in allowing a film of a test depicting the physical possibility that a car could be diverted onto railroad tracks). But see Swajian v. General Motors Corp., 916 F.2d 31, 36 (1st Cir. 1990) ("If a videotaped test is insufficiently comparable to the circumstances in the case, the videotape is inadmissible.").

${ }^{41}$ This type of videotape could potentially be used at any trial to provide the jury 
accident victim, ${ }^{42}$ to demonstrate a litigation theory, ${ }^{43}$ to record depositions, ${ }^{44}$ and to reconstruct the occurrence of an accident. ${ }^{45}$

with a view of a background area, method of operation, accident scene, or environmental situation. See GREgORY P. JOSEPH, MODERN VISUAL EVIDENCE § 4.03 (1993); see also Petty v. Ideco, 761 F.2d 1146, 1151 (5th Cir. 1985) (holding that the lower court did not err in allowing a videotape to illustrate the operation of an allegedly defective well-servicing unit).

${ }^{12}$ The "day-in-the-life" video is used to illustrate to the jury the impact that an accident has had on the day-to-day functioning of the victim. See Bannister v. Town of Noble, 812 F.2d 1265, 1269-70 (10th Cir. 1987) (adopting the factors enunciated in Bolstridge v. Central Me. Power Co., 621 F. Supp. 1202 (D. Me. 1985), in judging the admissibility of day-in-the-life videos and noting that the showing of the film is within the discretion of the trial court); Bolstridge, 621 F. Supp. at 1203-04 (outlining the court's concerns with the day-in-the-life video and excluding the video in this particular instance); Grimes v. Employers Mut. Liab. Ins. Co., 73 F.R.D. 607, 610 (D. Alaska 1977) (holding that a day-in-the-life video is admissible because it creates an illustration of the injury that could not be duplicated by mere words).

This type of videotaped evidence has been the subject of much commentary. See J. Ric Gass, Defending Against Day in the Life Videos, in THE THIRd ANNUAL LITIGATION MANAGEMENT SUPERCOURSE 1992, at 143, 146 (PLI Litig. \& Admin. Practice Course Handbook Series No. 432, 1992) (discussing potential objections, strategies, and motions to counteract a plaintiff's use of the videos because they "will rivet the jury's attention like no other evidence and bring home to the most hardened heart the plight of a severely injured plaintiff"); Joseph M. Herlihy, Note, Beyond Words: The Evidentiary Status of "Day in the Life" Films, 66 B.U. L. REv. 133, 136 (1986) (arguing that day-in-the-life films present a serious hearsay danger); Aida M. Alaka \& Davidson Ream, Day-in-the-Life Films: Moving Pictures That Move the Jury?, FOR THE DEF., Dec. 1991, at 20, 20 (addressing legal arguments to bring about the evidentiary exclusion of the videos and noting that "[p]laintiffs have . . . learned that films can present a more persuasive picture of the nature and [extent] of a severe injury than other types of evidence").

${ }^{43}$ See Szeliga v. General Motors Corp., 728 F.2d 566, 567 (1st Cir. 1984) (holding that the lower court did not err in admitting videotape to demonstrate the effect of impact on a standard lug and nut arrangement of the axle mounting); Marks v. Mobil Oil Corp., 562 F. Supp. 759, 766-67 (E.D. Pa. 1983) (admitting expert opinion and a supporting videotaped reenactment of a tanker truck passing a Volkswagen to illustrate the aerodynamic effect of a speeding truck), aff'd mem., 727 F.2d 1100 (3d Cir. 1984).

${ }^{11}$ The use of videotaped depositions has become fairly commonplace in civil trials. See, e.g., Weiss v. Wayes, 132 F.R.D. 152, 154 (M.D. Pa. 1990) ("There is significant authority outlining the advantages to the fact-finder in viewing a videotape deposition rather than listening to the reading of a written transcript, usually by an attorney simulating the testimony of the witness."); Rice's Toyota World v. Southeast Toyota Distribs., Inc., 114 F.R.D. 647, 649 (M.D.N.C. 1987) ("A video deposition ... permit[s] the fact-finder to utilize a greater portion of his perceptive processes than when merely reading or listening to a stenographic deposition."). For an extensive discussion of the use of videotaped depositions, see JOSEPH, supra note 41, §§ 2.01-.06.

${ }_{15}$ See John C. Buchanan et Al., How to USE Video in LITIGation: A Guide to TEChNOLOGY, STRATEgIES AND TECHNiques 197 (1987) (noting that accident reconstruction is used to "permit the court and jury to actually visualize what happened to cause an accident" and to "reconstruct how the expert believes the 
Videotaped evidence has extensive applicability in criminal trials as well, although frequently courts subject its use to an enhanced standard of review. In criminal cases, "evidentiary concerns often have constitutional impact, and courts generally tend to be more strict in insuring accuracy, avoiding confusion, and requiring advance disclosure of the evidence. ${ }^{n 6}$ Videotaped evidence has been utilized to record police lineups, ${ }^{47}$ criminal confessions, ${ }^{48}$ police surveillance work, ${ }^{49}$ arrests of drunk drivers, ${ }^{50}$ and crime scene reenactments. ${ }^{51}$ Thus, courts are well acquainted with

accident must have occurred ${ }^{n}$ ); Elizabeth A. Savage, Comment, Videotaped Reenactments in Civil Trials: Protecting Probative Evidence from the Trial Judge's Unbridled Discretion, 24 J. MARSHALl L. REv. 433, 437-38 (1991) (arguing that as technology advances, reevaluation of Rule 403 is necessary in order to bring about consistent regulation of admission); see also Datskow v. Teledyne Continental Motors Aircraft Prods., 826 F. Supp. 677, 685 (W.D.N.Y. 1993) (finding no error in the admission of a videotaped reenactment utilized to "help the jury understand the expert's opinion as to what happened," but cautioning the jury that the video was "not meant to be a re-creation of the accident'"). For a more complete discussion of this particular use of videotape, see infra part II.A.

${ }^{46} \mathrm{Joseph}$, supra note 39 , at 466 .

47 See JOSEPH, supra note 41, §5.06[1] (noting that "[v]ideotape recordings of properly conducted lineups and resulting identifications are becoming extraordinarily commonplace").

${ }^{48}$ Videotaped confessions are frequently admitted into evidence and are often considered a guarantee of "voluntariness" in making admissions. See Hendricks v. Swenson, 456 F.2d 503, 506 (8th Cir. 1972) (holding that the lower court did not err in admitting the videotaped confession because such a confession functions as a "modern technique to protect a defendant's rights").

19 Surveillance videos are utilized widely by law enforcement agencies to monitor suspected criminal activity, and their admittance at trial has been accepted extensively. This type of videotaped evidence gained public acclaim for its success during the FBI sting operation known as Abscam, which targeted several U.S. Congressmen. See, e.g., United States v. Weisz, 718 F.2d 413, 437 (D.C. Cir. 1983) (holding that the FBI has no obligation to record conversations that will exculpate as well as those that will inculpate); United States v. Williams, 705 F.2d 603, 611 (2d Cir.) (holding videotaped evidence of incriminating conversations admissible), cert. denied, 484 U.S. 1007 (1983); United States v. Myers, 692 F.2d 823, 859-60 (2d Cir. 1982) (holding that because the videotaping of defendant's conversations with undercover agents did not violate the Fourth Amendment the videotapes were admissible), cert. denied, 461 U.S. 961 (1983); United States v. Murphy, 642 F.2d 699, 700 (2d Cir. 1980) (holding videotapes of acceptances of bribes admissible).

${ }^{50}$ The Supreme Court has accepted police use of videotape to record the physical sobriety testing of motorists suspected of driving under the influence of alcohol. See Pennsylvania v. Muniz, 496 U.S. 582, 604 (1990) (holding that a videotape of defendant's sobriety tests is admissible to the extent that legitimate police procedures were followed).

${ }^{51}$ Crime scene reenactments are the focus of this Comment and will be discussed in detail in later sections. See infra parts II, III.E-F. 
evidence presented to the jury in the form of a video and the concomitant problems ${ }^{52}$ that accompany its use..$^{53}$

\section{Perceived Advantages of Demonstrative Evidence}

Many commentators argue for increased use of demonstrative and visual evidence by practitioners due to its ability to make an impact on the trier of fact and "generate[] immediacy, credibility and excitement." ${ }^{\text {T4 }}$ Those who support its extensive application subscribe to the view that "it is easier and more effective to simply show jurors what is being described, rather than waste time and risk the confusion of jurors by relying solely on oral testimony. ${ }^{55}$ Yet, as this Comment discusses later, the exact advantages that proponents seek to gain from the presentation of videotaped crime scene reenactments contribute to the creation of unfair prejudice against criminal defendants. ${ }^{56}$

52 The use of videotaped evidence presents both logistical and evidentiary problems. See Sharon Panian, Comment, Truth, Lies, and Videotape: Are Current Federal Rules of Evidence Adequate?, 21 Sw. U. L. REv. 1199, 1205-14 (1992) (describing potential problems with the use of videotaped evidence, including possible editorial manipulation, technical limitations, cost, and misuse of outtakes); Savage, supra note 45 , at 435 ("Logistical problems that the videotaped reenactment and other forms of videotaped demonstrative evidence present include the proper placement of projection equipment, the necessity of standard interchangeable equipment, the cost of installing standard equipment in all courtrooms, and the proper storage of videotape as a court record in courthouses." (footnotes omitted)).

The scope of this Comment is confined to the evidentiary problems associated with the use of videotaped reenactments of crime scenes. See infra part III. The use of videotaped reenactments in criminal trials poses unique problems that, for the most part, are not encountered through the use of other forms of video in civil and criminal trials.

${ }^{33}$ The trial judge has broad latitude to admit videotaped evidence. Once admitted, that decision will generally not be disturbed unless an abuse of discretion or some other similarly egregious judicial error can be shown. See, e.g., Lies v. Farrell Lines, Inc., 641 F.2d 765, $773 \mathrm{n.9}$ (9th Cir. 1981) ("The admissibility of demonstrative evidence in particular is largely within the discretion of the trial judge.").

${ }^{54}$ GIVENS, supra note $28, \S 1.01$, at 3 ; see also JOSEPH, supra note $41, \S 1.01$ ("Modern visual evidence, in its various forms, is a potentially powerful courtroom stimulant for, and focus for the attention of, the finder of fact."); Thomas Brown, Visual Evidence: Animations Add a New Dimension, NAT'L L.J., May 27, 1991, at 19, 19 (" $[A]$ ttorneys recognize that juries and even judges have become accustomed to getting their information from media that are 'packaged' in more exciting, dramatic ways.").

${ }^{35}$ Betsy Berman, Note, Have Juries Gone to the Movies?-The Use of Videotape in the Courtroom, 12 AM. J. TRIAL ADVOC. 141, 142 (1988) (citing Marvin Belli, Demonstrative Evidence: Seeing Is Believing, 1981 PERS. INJ. ANN. 858, 859).

${ }^{56}$ See infra part III.D. 


\section{VIDEOTAPED REENACTMENTS AND FUTURISTIC TECHNOLOGY}

\section{A. Reenactments in Civil Trials ${ }^{57}$}

Although the judiciary has widely accepted videotaped evidence in civil trials, ${ }^{58}$ courts frequently exercise closer scrutiny of videotaped reenactments due to their recognized potential to cause prejudice to the opposing party. ${ }^{59}$ In Datskow $v$. Teledyne Continental Motors Aircraft Products, ${ }^{60}$ the executrix of decedents' estates sued the maker of the aircraft in which decedents were flying after the aircraft caught fire and crashed, causing the death of all four passengers. ${ }^{61}$ The plaintiff commissioned the services of "a mechanical engineer with a background in accident reconstruction" to prove that a defect in the fuel system caused a leak, resulting in the fire. ${ }^{62}$ The trial judge allowed the jury to view a "videotaped computer-generated animation which illustrated [the expert's] theory of where the fire began inside the engine and how it spread." ${ }^{23}$ In allowing the video, the court.went to great lengths to caution the jury that the video should only be used to assist in comprehending the expert's opinion and should not be considered a reenactment of the accident and the surrounding events. ${ }^{64}$

Although their testimony is subject to closer scrutiny, accident reenactment experts are frequently commissioned for use in trials, and their testimony can support a verdict. ${ }^{65}$ The court in Conti $v$.

${ }^{57}$ For an extensive discussion of the use of videotaped reenactments in civil trials, see Savage, supra note 45 , at $446-57$.

${ }^{58}$ See supra notes 38-45 and accompanying text.

${ }^{59}$ See JOSEPH, supra note $41, \$ 4.05$ [1] ("[I]n contrast to the judicial reception accorded other forms of videotape evidence there has been considerable judicial reluctance to admit reconstruction tapes offered for the purpose of demonstrating how an incident in issue occurred."); see also Randall v. Warnaco, Inc., 677 F.2d 1226, 1234 (8th Cir. 1982) (holding that an attempt to duplicate the scene of a fire using a similar tent and stove in order to demonstrate certain physical properties made the "experimental evidence . . . very close to a reenactment of the accident, and as such its admission could be deemed unduly prejudicial").

${ }^{60} 826$ F. Supp. 677 (W.D.N.Y. 1993).

${ }^{61}$ See id. at 681 .

${ }^{62}$ Id. at 682 .

${ }^{63} I d$. at 685 .

${ }^{64}$ See id. (citing the trial judge's cautionary instruction to the jury with approval where the trial judge warned that the animation was "not meant to be a re-creation of the accident,' but [was] 'simply computer pictures to help you understand [the expert's] opinion'").

${ }_{65}$ See, e.g., Hinds v. General Motors Corp., 988 F.2d 1039, 1042 (10th Cir. 1993) (holding that the lower court did not err in allowing the plaintiffs to utilize the services of "an expert in accident reconstruction and occupant kinematics" who 
Ford Motor $\mathrm{Co}^{66}$ allowed the jury to view a filmed reenactment of the start-up of the alleged injury-causing automobile. ${ }^{67}$ A husband and wife sued Ford for injuries occurring when the husband-plaintiff neglected to depress the clutch while starting their manual transmission automobile. ${ }^{68}$ The wife-plaintiff was injured when the car lurched backward upon the turning of the ignition key. ${ }^{69}$

In finding no error in the admission of the reenactment on motion for a new trial, the court noted that the video "was merely helpful demonstrative evidence, and the differences between the reenactment and the actual accident were clearly and repeatedly explained. ${ }^{n 0}$ Thus, civil reenactments, though meriting closer supervision than other forms of videotaped evidence, are generally permitted upon satisfaction of certain fairness and accuracy requirements.

Courts will not hesitate to exclude videotaped reenactments and videos in general in civil trials when certain conditions are found, or (as the case may be) are not found, to exist. ${ }^{71}$ Generally, the tests performed in the reenactment must be similar to the situation presented before the trier of fact. ${ }^{72}$ Furthermore, the tests in the

"testified to the manner in which the accident occurred and the movements of [plaintiff's] body . . . following [the] collision"); Harrison v. Sears, Roebuck \& Co., 981 F.2d 25, 28 (1st Cir. 1992) (holding that the lower court did not err in allowing defendant's engineering expert to "utilize an x-ray of [plaintiff's] hand" to reconstruct the cause of plaintiff's injury); Caiazzo v. Volkswagenwerk A.G., 647 F.2d 241, 248 (2d Cir. 1981) (holding that the lower court did not err in allowing plaintiff to commission an accident reconstruction expert to testify "regarding the manner of ejection [from the vehicle] and the kinematic effects of the accident sequence").

65578 F. Supp. 1429 (E.D. Pa. 1983).

${ }^{67}$ See id. at 1432 (holding that the lower court did not err "in permitting the jury to view a filmed re-enactment of the start-up of the vehicle").

${ }^{68}$ See id. at 1430 .

${ }^{69}$ See id.

${ }^{70} \mathrm{Id}$. at 1432 .

71 The exclusion of a videotaped reenactment generally occurs under the Rule 403 balancing test. The test dictates that evidence shall be excluded where prejudice to the party is found to substantially outweigh the probative value of the evidence offered. See FED. R. EVID. 403. Rule 403 is discussed extensively infra part III.

${ }^{2}$ See, e.g., Chase v. General Motors Corp., 856 F.2d 17, 19 (4th Cir. 1988) (holding that the lower court erred in allowing the jury to view video tests that were so dissimilar to the conditions existing at the time of the accident "in such fundamental and important respects that the risk of prejudice ... outweighed the probative value of the evidence" (citing Gladhill v. General Motors Corp., 743 F.2d 1049, 1052 (4th Cir. 1984))); Hale v. Firestone Tire \& Rubber Co., 756 F.2d 1322, 1333 (8th Cir. 1985) (holding that the "district court abused its discretion in permitting the film to be shown when the conditions of the experiment were admittedly substantially different from the conditions of the accident in this case"); 
reenactment must also "fairly and accurately" represent the facts of the case. ${ }^{73}$ The court may also choose to exclude the videotaped evidence when its presentation can be considered cumulative or duplicative in light of other available testimony. ${ }^{74}$ The critical evidentiary hurdle the reenactment must pass is that it must not create unfair prejudice against the opposing party. ${ }^{75}$ Thus, though courts are amenable to the use of videotaped reenactments in civil trials, they monitor their use closely. The enhanced scrutiny given to reenactments in civil trials stands in sharp contrast to the laissezfaire attitude generally taken by the courts with regard to other forms of videotaped evidence. ${ }^{76}$

This examination of the judicial treatment accorded videotaped evidence in civil and criminal trials illustrates a continuum of "decreasing" admissibility. When the videotaped evidence in a civil trial can be regarded as attenuated or related to a collateral matter, such as in the case of recorded depositions or the scenes of accidents, the videotape's acceptance level can be considered routine or high. But, as the content of the videotaped evidence moves closer to dramatizing the issues in dispute (such as in the case of reconstruction in civil cases), judicial scrutiny and instances of exclusion increase. Thus, the recognition that courts will apply a heightened standard of review to certain forms of videotaped evidence in both civil and criminal settings serves as a harbinger of

Gladhill, 743 F.2d at 1051 (holding that the trial court erred in allowing a videotaped demonstration where "the circumstances of the accident, as alleged, are so different from this test as to make the results largely irrelevant if not misleading").

${ }^{73}$ See, e.g., Slakan v. Porter, 737 F.2d 368, 378 (4th Cir. 1984) (allowing the jury to view a video depicting the water pressure and hose nozzle used against the plaintiff where "the videotape accurately and fairly depicted the force applied against [plaintiff]" and posed no danger to the trial outcome).

${ }^{74}$ See, e.g., Thomas v. C.G. Tate Constr. Co., 465 F. Supp. 566, 571 (D.S.C. 1979) (holding that the exclusion of a video depicting the burns of a severely injured plaintiff was proper where "not only [would] the plaintiff be available to testify, but the doctor, the wife, and the therapist" also would be available to testify to the extent of the injuries).

${ }^{75}$ Unfair prejudice is the baseline against which all evidence must be measured. Therefore, even if the evidence meets all other judicial requirements, it may still be excluded under Rule 403. See infra part III (discussing Rule 403 and its role in the overall scheme of the evidentiary code); see also Swajian v. General Motors Corp., 916 F.2d 31, 36 (1st Cir. 1990) (holding that even if the circumstances in the reenactment are sufficiently similar to the situation at bar, "their showing to the jury is still subject to a Rule 403 analysis").

${ }^{76}$ See supra notes $38-45$ and accompanying text (discussing the acceptance of various forms of videotaped evidence in civil trials). 
the even closer judicial examination that courts confronting the issue have given criminal reenactments. ${ }^{77}$

\section{B. Reenactments in Criminal Trials}

\section{The Effects of Technology-Predictions for the Future}

The Mitchell and Spath rulings ${ }^{78}$ signified a substantial departure from traditional judicial philosophy concerning reenactments in light of advancing technology. ${ }^{79}$ Current computer and video technology is approaching the point where the practitioner will be able to create and reconfigure exhibits while in the courtroom. ${ }^{80}$

77 This closer scrutiny is commensurate with other protections that criminal defendants receive over their civil counterparts, including the prohibition against double jeopardy, see U.S. CONST. amend. V, cl. 2; the privilege against self-incrimination, see id., amend. V, cl. 3; the right to confront witnesses, see id., amend. VI, cl. 2; and the right to compulsory process of witnesses, see id., amend VI, cl. 3.

${ }^{78}$ See supra notes 1-25 and accompanying text (discussing the Mitchell and Spath trials).

${ }^{79}$ See Jeffrey Beer, 3-Dimensional Desktop Animation: Fake Reality Is Coming to a PC Near You, CD-ROM PROF., Nov. 1992, at 33, 33-34 (describing latest developments in three-dimensional modeling software programs and their application to the Mitchell trial); Brown, supra note 54, at 19 ("Technology is changing the nature of the evidence offered in American courtrooms"); Henke, supra note 20, at 434-36 (discussing the variables involved in producing computer-generated animated reconstructions); Gregory P. Joseph, In Court, One Imaging System Is Worth a Thousand Documents, N.Y. L.J., July 19, 1993, at S4 (describing uses of imaging systems technology to ease the burden of handling papers, charts, and videotapes in the courtroom); Richard Morochove, Design Your Own Office or Recreate a Murder with This Firm's Software, TORONTO STAR, July 27, 1992, at C3 (discussing the commonly used computer software that generated the animation used at the Milchell trial); Howard L. Nations \& Douglas Filter, Computerized Graphics Find Larger Role, N.Y. L.J., July 27, 1992, at S8 (surveying types of computer-generated evidence and restrictions courts have placed on such evidence); Fred Setterberg, Roger Rabbit Goes to Court, CaLIF. LAw., Feb. 1990, at 70, 70 (describing various applications of computer graphics in producing demonstrative evidence); Sherman, supra note 9, at 1 (referring to the use of computer animation as "a technological revolution" in criminal trials); Marshall S. Turner \& Andrew T. Houghton, Interactive Animations are Wave of the Future, N.Y. L.J., Feb. 16, 1993, at $S 1$ (heralding technological innovations allowing litigators to create unlimited and immediately adaptable forms of animation evidence).

${ }^{80}$ See Turner \& Houghton, supra note 79, at S1 ("Interactive computer graphics give the litigator an unlimited and immediately adaptable form of visual presentation. They are flexible enough to be used not only during planned direct testimony, but also during cross-examination, redirect, and opening and closing arguments.").

Over the course of the last decade, demonstrative evidence has "changed in kind, not just in degree." Brain \& Broderick, supra note 28, at 963.

With the advent of relatively low-cost but powerful computers and sophisticated computer graphics software, demonstrative proof has changed from the "state-of-the-art" brightly colored charts and nascent day-in-the-life 
Desktop computer software can now be utilized to create threedimensional graphics, as well as more basic charts, diagrams, and crime scenes. ${ }^{81}$ As a result, "it is becoming increasingly possible for home-based electronic[s] ... to create broadcast-quality resolution images that rival the very best images seen on TV. ${ }^{\text {82 }}$ For example, the reenactment prepared for the Mitchell trial was created by an expert using a form of virtual reality. ${ }^{83}$

Although technology has advanced to allow practitioners to create their own demonstrative evidence, this technological leap does not obviate the prejudice that occurs when the evidence is viewed by the jury. ${ }^{84}$ In fact, the technology may serve to enhance the prejudice that occurs because the graphics may now be created by practitioners who are attempting to obtain favorable judgments for their clients in both civil and criminal courts. Noting the effects of this technology, one practitioner commented that " $[t]$ he people that are offering [the reenactment] into evidence are the same people who produce it, direct it and star in it [and] they [then] get on the stand and ... critique it."'85 Thus, as technology eases the

films of the early 1980's to professionally produced movies, imprinted on laser discs, dramatically depicting, for example, an expert's opinion of what the pilot saw from the cockpit during the last fifteen minutes before an airplane crash, or the causes of a complicated accident at a hexane production plant. Within the next decade or so, even these types of demonstrative exhibits will seem tame, as then-state-of-the-art demonstrative proof will be even more powerful. Technology will soon be available for a witness to don a "body suit" in the courtroom, step into a three-dimensional reconstruction of the scene, and illustrate exactly what she says occurred at the relevant locale by interacting in real time with the objects on the screen.

Id. (footnotes omitted).

${ }^{81}$ Although the software is relatively expensive, new developments "represent[] a gigantic leap forward in bringing broadcast-quality, high-powered rendering tools to artists and other graphics professionals with limited resources." Beer, supra note 79 , at 34 . In addition, more basic software can provide "visual evidence solutions to the perennial problem of explaining in court complex business, scientific, medical or engineering concepts." Setterberg, supra note 79 , at 70 .

${ }^{82}$ Beer, supra note 79 , at 34 .

${ }^{83}$ See Joan Hamilton, Is VR Real Enough for the Courtroom?, Bus. WK., Oct. 5, 1992, at 99 (noting that the crime scene was re-created "on a personal computer using computer-aided design software"). Virtual reality is a form of computer technology that allows users to create realistic images in a variety of settings. See also Morochove, supra note 79, at C3 (illustrating the effectiveness of the software used to re-create the Mitchell crime scene and pointing out that the software enables the user to "zoom in close for details, without waiting for the time-consuming process of a screen regeneration to redraw the design").

${ }^{8}$ See infra part III.D.

${ }^{85}$ Sherman, supra note 9 , at 32 . 
burden and cost for practitioners to create videotaped reenactments, the more likely it becomes that such evidence will be utilized in the courtroom.

The following Section details the treatment that the videotaped reenactment has been accorded in various state appellate courts prior to the rulings in Mitchell and Spath. ${ }^{86}$

\section{A Look Back to Lopez v. State $e^{87}$ The Mule}

Robert Lopez got caught. Lopez was arrested as part of a standard drug sting-a "buy and bust" operation conducted by the Fort Worth, Texas, police department. ${ }^{88}$ An undercover officer set up a drug buy at a local motel where Lopez, assisting two accomplices, was caught driving the backup car during the attempted transaction. ${ }^{89}$ As part of its trial presentation, the prosecution prepared a videotaped reenactment to assist the jury in visualizing the scene at the motel. ${ }^{90}$ Created through the recollections of the officers at the scene and "consist[ing] of individuals dressed in casual wear driving cars around a motel parking lot, ${ }^{911}$ the reenactment totaled " 2 to 3 minutes in length and was stopped at various points to allow police officer witnesses to narrate the event shown. ${ }^{\text {92 }}$ The reenactment was fairly primitive in light of today's technology: "black and white, shot at a distance and silent."

The trial judge allowed the reenactment to be viewed over the defendant's objection, and Lopez was eventually convicted by the jury. ${ }^{94}$ Lopez appealed, arguing, inter alia, that the use of the videotaped reenactment was reversible error. ${ }^{95}$ The Texas Court

${ }^{86}$ This Section will focus on state court rulings concerning the admission of crime scene reenactments. Although the focus of this Comment is the admissibility of reenactments under the Federal Rules of Evidence, the rules reach a majority of the states. See infra part III.A. Federal courts have yet to rule on the admissibility of videotaped crime scene reenactments.

${ }^{87} 651$ S.W.2d 413 (Tex. Ct. App. 1983).

${ }^{8}$ See id. at 413.

${ }^{89}$ See id.

${ }^{90}$ See id.

${ }^{91} \mathrm{Id}$. at 414.

92 Id.

${ }^{93} I d$. The reenactment used in the Mitchell trial, on the other hand, depicted colored graphics, moving forms, and changing angles. See Curtis, supra note 4, at A1, A6; see also infra part II.B.4.a.

${ }^{9}$ Lopez was convicted of aggravated delivery of marijuana and sentenced by the jury to sixteen years in prison as well as fined fifty thousand dollars. See 651 S.W.2d at 413 .

${ }^{95}$ See id. 
of Appeals agreed, holding that "any staged, re-enacted criminal acts or defensive issues involving human beings are impossible to duplicate in every minute detail and are therefore inherently dangerous, offer little in substance and the impact of re-enactments is too highly prejudicial to insure the State or the defendant a fair trial. ${ }^{n 6}$ Although the court did not articulate a specific evidentiary criteria or standard for review, ${ }^{97}$ after a thoughtful analysis the court found the reenactment to be "prejudicial. ${ }^{\text {98 }}$

The court rejected the prosecution's contention that the reenactment was nothing more than "a series of posed pictures" and instead expressed concern over potential dangers inherent in the admission of the reenactment. ${ }^{99}$ The court first noted the general effect of videotaped evidence on a jury and the forceful mental impression it creates. ${ }^{100}$ The court then articulated the negative effects videotaped evidence imposes on the perceptions of individual jurors, possibly outweighing the force of other evidence. ${ }^{101}$ The court's concern was that " $t]$ he general appearance of an actor, his facial expression or slightest gesture whether intended or not may sway a juror who has listened to lengthy testimony. ${ }^{\text {102 }}$ Troubled by the potential impact of videotaped reenactments on the cognitive sensibilities of the jury, ${ }^{103}$ the Texas Court of Appeals precluded their use in evidence in subsequent trials. ${ }^{104}$

${ }^{96} I d$. at 416 . Thus, the Court of Appeals, in reversing the conviction, created a broad-based judicial ban on videotaped reenactments.

${ }^{97}$ Texas is one of the many states that has enacted the Federal Rules of Evidence in its entirety. See infra note 187 and accompanying text. Thus, the logical assumption may be that the decision was made under Rule 403 of the Texas Rules of Criminal Evidence, a provision identical to Rule 403 of the Federal Rules of Evidence. Compare TEX. R. CRIM. EvID. 403 with FED. R. EVID. 403. See infra notes 209-38 and accompanying text (discussing Federal Rule 403).

${ }^{98}$ Lopez, 651 S.W.2d at 416.

${ }^{99}$ Id. at 414.

${ }^{100}$ The court argued that "[a] motion picture of the artificial recreation of an event may unduly accentuate certain phases of the happening, and because of the forceful impression made upon the minds of the jurors by this kind of evidence, it should be received with caution." Id. (quoting People v. Daab, 197 P.2d 1, 5 (Cal. 1948)). The impact on the jury noted by the Daab court and the Lopez court forms the crux of the argument to exclude videotaped reenactments from criminal trials. See infra part III.D.

${ }^{101}$ See Lopez, 651 S.W.2d at 415. Furthermore, the court believed that the "danger of jurors branded with television images of actors, not testimony, is too great to ascertain." Id.

${ }^{102} \mathrm{Id}$.

${ }^{103}$ The court also expressed concern that prosecutors and defendants would compete for jury attention by creating "dueling" videos. See $i d$.

${ }^{104}$ Id. at 416 . In formulating its decision, the court looked to the Supreme Court 


\section{Post-Lopez Treatment}

Lopez v. State is the most searching and thorough judicial analysis of the admissibility of a videotaped reenactment. Several other courts have reached similar conclusions without conducting an indepth examination of potential prejudice to the defendant. This Section's purpose is to track the reasoning of those courts to create a typology for the exclusion of reenactments at criminal trials.

\section{a. State v. Hopperstad ${ }^{105}-$ The Disorderly}

The details of John Hopperstad's arrest were sparse. ${ }^{106}$ Following Hopperstad's arrest for disorderly conduct, ${ }^{107}$ the prosecution, over defendant's objection, presented to the jury a videotaped reenactment of the events surrounding Hopperstad's arrest. $^{108}$ Following his conviction, Hopperstad argued, as Lopez did, that showing the jury the reenactment was reversible error. ${ }^{109}$

The Minnesota Court of Appeals agreed, citing two distinct grounds for excluding the reenactment. First, the court found that the reenactment was not probative of any material facts in dispute, concluding that "[a] dramatization of one side's account of what happened ... does not 'tend to prove or disprove a material fact in issue." 110 In reaching this conclusion, the court simply stated that

of Wyoming's decision in Peterson v. State, 586 P.2d 144 (Wyo. 1978), for guidance. See Lopez, 651 S.W.2d at 415. In Peterson, the court held that no error was committed in excluding a videotaped reenactment presented by the defendant. See Peterson, 586 P.2d at 154. The defendant attempted to reenact the circumstances leading to his arrest by consuming substantial quantities of alcohol to record his responses. See id. The court, using a formulation identical to Federal Rule 403 (at that time, not yet enacted in Wyoming), found that the exclusion was within the discretion of the trial judge and was proper since the circumstances surrounding the reenactment were substantially different from the actual events. See $i d$.

${ }^{105} 367$ N.W.2d 546 (Minn. Ct. App. 1985).

106 The court simply notes that he was arrested for "disorderly conduct following a scuffle at the Law Enforcement Center in Austin[, Minnesota]." Id. at 547. Presumably, Hopperstad was involved in some form of disturbance outside the police station.

${ }^{107}$ It is interesting to note that the prosecution expended time and expense in creating a videotaped reenactment for Hopperstad's trial even though a disorderly conduct charge in Minnesota is only a misdemeanor. See id. at 547-48 (citing AusTIN, MINN., ORDINANCES $\$ 10.06(3)$ ).

${ }^{108}$ See id. The reenactment was created as part of the internal police investigation file. See id.

${ }^{109}$ See id. at 549.

${ }^{110}$ Id. (quoting MINN. R. Evid. 401). The court, utilizing an evidence code identical to the Federal Rules of Evidence, cited to Rules 401 and 402 of the 
"we doubt the relevance of the videotaped reenactment of the incident that led to the defendant's arrest."111

In addition to finding the videotape lacked probative value, the Hopperstad court found the reenactment to be prejudicial because its presentation could potentially impact the jury in a manner disproportionate to its evidentiary value. ${ }^{112}$ Arguing that the videotaped reenactment violated "basic fairness," the court, utilizing reasoning paralleling Lopez, concluded that "[s]eeing the events depicted exactly as the State's witnesses said they happened is bound to affect the jury out of all proportion to its value as evidence."113 Following this cursory analysis, the court reversed Hopperstad's conviction and remanded for a new trial. ${ }^{114}$

\section{b. State v. Trahan ${ }^{115}-$ The Murderer}

Ty Trahan's case could be described as a typical lover's quarrel, except for its tragic ending. ${ }^{116}$ Trahan was arrested for the murder of his ex-girlfriend. ${ }^{117}$ Witnesses testified that Trahan and the victim had argued repeatedly throughout the night over the victim's relationships and interest in men other than Trahan. ${ }^{118}$ Trahan testified that he had been drinking continuously for approximately twelve hours prior to the murder. ${ }^{119}$

From the prosecution's point of view, the state possessed a solid case against Trahan: a motive, the murder weapon, and extremely

Minnesota Rules of Evidence in reaching its conclusion. See MINN. R. EvID. 401, 402. Essentially, the court resorted to its judicial instincts to find the reenactment not relevant. See infra note 177 and accompanying text (discussing Federal Rules 401 and 402).

${ }^{111}$ Hopperstad, 367 N.W.2d at 549.

112 The court looked to Minnesota Rule of Evidence 403, a rule identical to its federal counterpart, and found the reenactment to be prejudicial as well as irrelevant. See id. The court also cited further concern for the videotape's probative value: it argued that the reenactment was "cumulative" and that it "only restated graphically the testimony of the State's preceding three witnesses." Id.

${ }^{113} \mathrm{Id}$.

${ }^{114}$ See id.

${ }^{115} 543$ So. 2d 984 (La. Ct. App. 1989), overruled on other grounds by State v. Simpson, 551 So. 2d 1303, 1304 (La. 1989), but aff d, 576 So. 2d 1 (La. 1990). Although this case deals with a defendant's attempt to have a videotaped crime scene reenactment viewed by the jury, it raises similar concerns as prosecution attempts to present a reenactment.

116 The defendant and the victim had been dating during the six weeks leading up to the murder. See id. at 988.

117 See id. at 989.

${ }^{118}$ See id. at 988.

${ }^{119}$ See id. at 989. 
favorable forensic evidence. ${ }^{120}$ To counteract the weight of the evidence, the defendant and his experts created a videotaped reenactment of their account of the fatal encounter and attempted to have it shown to the jury. ${ }^{121}$ After screening the reenactment, the trial judge excluded the evidence, finding that "the reconstruction did not accurately depict the condition or the position of the parties." 122 Trahan was convicted of second-degree murder. ${ }^{123}$

Upon review, the Louisiana Court of Appeal upheld the trial court's decision to exclude the reenactment, citing the reconstruction's lack of probative value and hinting at the potential prejudice the reenactment could cause. ${ }^{124}$ The court found that the factual inaccuracies cited by the trial judge vitiated the reenactment's probative value and that " $[t]$ he reconstruction was, therefore, inconclusive in relation to its ability to corroborate defendant's story. ${ }^{125}$ In addition, the court found that the reenactment would affect judicial economy by implicating collateral issues, serving only to repeat testimony and confuse the jury. ${ }^{126}$ In all likelihood, the court noted its concerns about judicial economy and accuracy to allude to the potential prejudice the reenactment could engender. In this case, however, the defendant, not the prosecution, made the presentation. As such, the concerns of potential prejudice that Rule 403 attempts to counter are not nearly as prevalent.

${ }^{120}$ See id. at 988-89.

121 Trahan argued that the videotaped reenactment "corroborated [his] version of the incident and rebutted the opinion of the state expert who had earlier testified that [his] version [of the events] was impossible." Id. at 996.

${ }^{122} I d$. at 997.

${ }^{123}$ Trahan was sentenced to life in prison without parole, probation, or suspension of sentence. See id. at 987.

${ }^{124}$ See id. at 997 . Louisiana has adopted the Federal Rules of Evidence, so presumably the court made its decision based upon Rule 403 of the Louisiana Rules of Evidence, although it makes no mention of the rule in its decision. See LA. CodE EviD. ANN., art. 403 (West 1994). For a discussion of Federal Rule 403, see infra part III.C.

${ }^{125}$ Trahan, 543 So. $2 \mathrm{~d}$ at 997 . The court further stated that the "significant inaccuracy in the placement of the victim during the reconstruction practically eliminated the probative value of the videotape." Id.

${ }^{226}$ The court stated that

the reconstruction presented a potential that collateral issues would be raised which would be unduly time consuming and confusing to the jury. Defendant testified fully as to his version of the incident. Defense counsel fully cross-examined the state's expert and in fact elicited the contested testimony of whether certain physical maneuvers were possible.

Id. 


\section{c. State v. Caudill ${ }^{127}-$ The Intruder}

Like Ty Trahan, Gordon Caudill let the emotions of personal life get the better of him. Caudill was arrested at the scene of the shooting of his former employer and charged with several crimes. ${ }^{128}$ Not only did Caudill have "a previous employer/ employee relationship" with the victim, but he had a "romantic relationship" with her as well. ${ }^{129}$ Upon the termination of their romantic relationship, Caudill broke into the victim's house and shot her twice. ${ }^{130}$ Caudill did not dispute that he actually performed the physical acts constituting the crimes, but contested all the charges on the grounds that he was unable to form the requisite criminal intent because of insanity. ${ }^{131}$

Although the facts of the incident were uncontroverted, the trial judge allowed the prosecution to present a videotaped reenactment of the incident over the defendant's objection. ${ }^{132}$ The reenactment was prepared by the Sheriff's Department a short time after the incident; the victim played herself, and a deputy sheriff played the part of the defendant. ${ }^{133}$ The videotape "depict[ed] a deputy sheriff looking through [the victim's] window as she stood in the kitchen." 134 The scene then shifted to the deputy "stepp[ing] in and out of the doorway to the bedroom, acting as if he was firing a gun by pointing his finger at her, and then coming into the bedroom, acting as if he was continuing to fire a gun at her." 135 Following his conviction, Caudill appealed, challenging the showing of the reenactment.

The Missouri Court of Appeals found itself presented with a novel issue of evidentiary law, but did not undertake an indepen-

127789 S.W.2d 213 (Mo. Ct. App. 1990).

${ }^{128}$ Caudill was charged with assault, armed criminal action, burglary, and the unlawful use of a weapon. See id. at 214.

${ }^{129} I d$.

${ }^{130}$ See id. The facts of the case were undisputed. Caudill fired one shot at the victim through her kitchen window, striking her in the arm. See id. He then subsequently broke into the house and followed the victim into her bedroom, where he fired two more shots, one of which struck the victim in the leg. See id. At this point, Caudill exhausted his supply of bullets and the victim retrieved her own shotgun, firing one shot, which struck Caudill in the abdomen. See id.

${ }^{131}$ See id. ("At trial [Caudill] relied on a defense of not guilty by reason of mental disease or defect.").

132 See id. at 215.

139 See id.

${ }^{134}$ Id. at 216.

${ }^{195}$ Id. 
dent analysis of the merits of the reenactment. ${ }^{136}$ Instead, the court considered the merits of numerous other state court decisions, ${ }^{137}$ eventually deferring to the logic of Lopez $v$. State. ${ }^{138}$ In accepting the logic of Lopez, the court cited concerns for the difficulty in re-creating human events, the appearance of the participants in the reenactment, and the powerful effects of television. ${ }^{139}$ Although finding that the use of the videotaped reenactment was error, ${ }^{140}$ the court nevertheless concluded that the error was harmless ${ }^{141}$ and affirmed the verdict. In arriving at its broad-based exclusion of reenactments, the court failed to conduct an independent evidentiary analysis and merely adopted a prior court's analysis.

\section{Mitchell and Spath ${ }^{142}-$ The Judicial Philosophy Shifts}

\section{a. People v. Mitchell ${ }^{143}$-The Porn Czar}

During Jim Mitchell's trial for the murder of his brother, ${ }^{144}$ the prosecution did not present or possess any eyewitnesses to buttress its theory of the case. ${ }^{145}$ Therefore, the state commissioned an expert to create a computerized videotaped reenactment utilizing

${ }^{136}$ See id. ("No such Missouri case [concerning the admissibility of a videotape reenactment of a crime] has been found. Other jurisdictions, however, have had occasion, in criminal cases, to address the admissibility of videotape evidence which goes beyond merely recording the scene of a crime.").

${ }^{137}$ See id. (noting State v. Hopperstad and State v. Trahan). For a discussion of the Hopperstad and Trahan cases see supra parts II.B.3.a-b.

138 See $i d$. ("The most convincing case dealing with the admissibility of a videotape reenactment of a crime ... . is from the Texas Court of Appeals.").

${ }^{139}$ See id. For a discussion of Lopez, see supra part II.B.2.

${ }^{110}$ See id. ("A videotape reenactment of a crime ... where the victim reenacts the crime with a third party playing the role of the defendant, should be and is hereby declared inadmissible in Missouri.").

${ }^{141}$ See id. at 217 ("In the case at bar there is no reasonable doubt that [defendant] would have been found guilty as charged without the admission of . . . the videotape reenactment.").

${ }^{142}$ It is noteworthy that Jim Mitchell and Gary Spath share much in common in the context of the legal issues both faced. Outside of their similar legal contexts, however, they could not be more different. Mitchell, the controller of a far-reaching pornographic empire, constantly under legal scrutiny, stands in contrast to Spath, the young police officer attempting to maintain order in an urban environment.

${ }^{113}$ No. 12462 (Cal. Super. Ct. Marin County indictment filed Sept. 17, 1991).

114 For the details surrounding Mitchell's arrest, see supra notes 1-6 and accompanying text.

145 See Abrams, supra note 1, at E18 ("No one saw the killing, although Artie's livein girlfriend ... testified that she was in the house."). 
forensic evidence and the prosecution's theory of the case to demonstrate the purported movements of the defendant throughout the victim's house. ${ }^{146}$ The prosecution created the reenactment to illustrate that the events of the evening were precipitated by the defendant, not by the victim. ${ }^{147}$

Despite its initial exclusion, ${ }^{148}$ the trial judge subsequently permitted a modified version of the reenactment to be shown to the jury at trial. ${ }^{149}$ The reenactment allowed the jury to view "colored lines representing different areas of the ... house where Artie was shot, an outline of a moving human form that was supposed to be the victim and swift-moving red lines that represented gunfire during the shooting. ${ }^{n 150}$ In addition, the reenactment could be altered to show various images and "[ $t]$ he images $c[$ ould] be changed to depict the scene from different angles, including overhead views." ${ }^{151}$ Mitchell was convicted, ${ }^{152}$ and he is currently appealing the verdict, relying in significant part on the use of the reenactment during the trial. ${ }^{153}$

\section{b. New Jersey v. Spath ${ }^{154}-$ The Cop}

Unlike the prosecution in Jim Mitchell's trial, prosecutors at Gary Spath's manslaughter trial had the benefit of several eyewitnesses. ${ }^{155}$ Regardless, the key issue in the case turned on whether the jury believed the prosecution's argument that Spath fired while the victim had his back turned, or the defense's argument that the victim was turning toward Spath when the officer fired..$^{156}$

${ }^{346}$ For a description of the technology used in the Mitchell reenactment, see supra part II.B.1.

${ }^{147}$ See Sherman, supra note 9, at 32 (noting that the reenactment was "designed to demonstrate the prosecution's contention that the victim's position and the timing proved the killing was a deliberate, premeditated act").

${ }^{148}$ The trial judge would not allow the video reenactment to be shown until "'prejudicial' assumptions that were not backed up by the evidence" were removed. Curtis, supra note 4 , at A6.

${ }^{149}$ See id. at Al.

${ }^{150} \mathrm{Id}$.

${ }^{351} I d$.

${ }^{152}$ Mitchell was sentenced to six years in prison and fined ten thousand dollars. See id.

${ }^{153}$ See id. ("[Mitchell's attorney] planned to attack as improper the prosecutor's use of a computerized video re-enactment of the crime . . . .").

154 No. SGJ263908 (N.J. Super. Ct. Crim. Div. filed Dec. 5, 1990).

${ }^{155}$ For a description of the fatal encounter, see supra notes 7-14 and accompanying text.

${ }^{156}$ See supra notes 14,17 and accompanying text. 
To assist in articulating their version of the events, the prosecution commissioned the creation of a reenactment to demonstrate that the victim had his hands in the air when he was shot and to show the trajectory of the bullet on entry into his body. ${ }^{157}$ Furthermore, the video contained an "additional, emotionally charged scene ... [depicting a] young, black male model running into a parking lot and spinning toward the camera with his arms held high. "158 The trial judge allowed the reenactment to be presented to the jury, ${ }^{159}$ although the prosecution eventually decided not to make use of it for strategic reasons. ${ }^{160}$ Spath was ultimately acquitted of any wrongdoing by the jury. ${ }^{161}$

\section{Analysis}

Prior to Spath and Mitchell, the majority of state appellate courts analyzing the use of videotaped reenactments in criminal trials favored their exclusion. ${ }^{162}$ The various courts addressing the issue have cited numerous factors in support of this proposition; the consensus, however, has articulated two dominant forms of prejudice impacting on the defendant's ability to receive a fair trial when a videotaped reenactment is utilized.

${ }^{157}$ See Henneberger, supra note 8, at 21 ("The state's case centers on a videotaped re-enactment of the shooting that shows that the bullet hole in [the victim's] parka lined up with the entry wound in the victim's back only when one or both of the models' arms are raised.").

${ }^{158}$ Sherman, supra note 9 , at 32.

${ }^{159}$ See Melinda Henneberger, Judge OKs Simulated Shooting, N.Y. NEWSDAY, Jan. 15, 1992, at 19; see also Sherman, supra note 9, at 22 (quoting presiding Judge DiGisi in a subsequent interview as saying that he "thought in this particular case it would be invaluable to understand what the expert was testifying to").

${ }^{160}$ See Melinda Henneberger, Shooting Expert Grilled, N.Y. NEwSDAY, Jan. 28, 1992, at 24.

${ }^{161}$ See Sherman, supra note 9, at 32.

162 See supra parts II.B.2-3. But see Lee v. State, 760 P.2d 1039, 1044 (Alaska Ct. App. 1988) (holding that the trial court did not err in admitting a videotape in which the victim reenacted her actions prior to being hit by defendant's car because the jury was made aware of the "various dissimilarities between the conditions in the video and the conditions at the time of the offense"); State v. Billings, 409 S.E.2d 707, 713 (N.C. Ct. App. 1991) (holding that the trial judge's decision not to exclude a videotaped reenactment was not error as the video only illustrated an earlier confrontation between the defendant and the victim, and the tapes "did not depict any conduct, incriminating or otherwise, of the defendant" ${ }^{n}$ ).

In both Lee and Billings, the reenactments viewed by the jury did not attempt to illustrate any culpable conduct committed by the defendant. Thus, the potential for prejudicial harm engendered by the reenactments that were eventually excluded in situations such as Lopez did not exist in either of these two cases. 
First, reviewing courts have articulated a concern for the potential impact that viewing the defendant, or a likeness of the defendant, committing the crime on videotape will have on the decision-making capabilities of the jury. ${ }^{163}$ Three of the four decisions analyzed-Lopez, Hopperstad, and Caudill-have considered this the primary reason for exclusion. ${ }^{164}$ The Lopez court expressed its concern: "The danger of jurors branded with television images of actors, not testimony, is too great to ascertain. No court instruction could remove highly prejudicial evidence of a re-enacted rape or murder if we establish this precedent. ${ }^{165}$ Because this impact is the primary concern of courts excluding such evidence, this Comment focuses on the impact of the reenactment on the cognitive processes of juries and the potential for error it generates in the decision-making process. ${ }^{166}$

Second, reviewing courts have also relied on the impact of videotaped reenactments on judicial economy and the fact-finding process as an exclusionary vehicle. ${ }^{167}$ The courts in Hopperstad and Trahan reasoned that presentation of reenactments at trial would be both repetitive and confusing. ${ }^{168}$ This argument is predicated on the notion that a reenactment is only a visualization of prior oral testimony and that oral testimony can adequately illustrate the circumstances of the criminal activity. ${ }^{169}$ Although

${ }^{16 s}$ See Lopez v. State, 651 S.W.2d 413, 414-15 (Tex. Ct. App. 1983) (finding that subtle gestures, facial expressions, or appearances may improperly sway juries); see also State v. Hopperstad, 367 N.W.2d 546, 549 (Minn. Ct. App. 1985) (finding that a videotaped reenactment did not "tend to prove or disprove a material fact in issue" and, even if the reenactment were relevant, it was cumulative and prejudicial); State v. Caudill, 789 S.W.2d 213, 216 (Mo. Ct. App. 1990) (citing Lopez); supra notes 87-114 and 127-41 and accompanying text (discussing Lopez, Hopperstad, and Caudill).

${ }^{164}$ See Lopez, 651 S.W.2d at 415; see also Hopperstad, 367 N.W.2d at 549 ("Seeing the events depicted exactly as the State's witnesses said they happened is bound to affect the jury out of all proportion to its value as evidence."); Caudill, 789 S.W.2d at 216 (citing Lopez).

${ }^{165}$ Lopez, 651 S.W.2d at 415.

${ }^{166}$ See infra part III.D.

${ }^{167}$ See State v. Trahan, 543 So. 2d 984, 997 (La. Ct. App. 1989) (fearing that collateral issues may be raised by inaccurate videotape reconstruction, unduly taking court time and confusing the jury), overmeled on other grounds by State v. Simpson, 551 So. 2d 1303, 1304 (La. 1989), but affd, 576 So. 2d 1 (La. 1990); Hopperstad, 367 N.W.2d at 549 (finding the videotape to present only "cumulative" evidence).

${ }^{168}$ See supra notes 111,126 and accompanying text.

${ }^{169}$ This argument does not carry the same logical strength as does the argument that the "viewing" of video in general prejudices criminal defendants. According to the "unnecessary visualization" critics, any form of demonstrative evidence that is not "real," whether it is a video, map, chart, or graph, is repetitive. Courts routinely allow the use of most forms of demonstrative evidence, however, regardless of their 
this determination runs counter to the present status of demonstrative evidence in the courts, the conclusion is in part a reference to the potential prejudice argument. ${ }^{170}$ Essentially, courts citing repetition and confusion do so for reasons of judicial caution. It is logical to reason that if other adequate means of articulating the aspects illustrated by the reenactment exist, there is no need to risk the potential prejudice that the reenactment may engender. Thus, prior to Mitchell and Spath, ${ }^{171}$ the exclusion of videotaped reenactments was, for the most part, the rule and not the exception.

In Mitchell and Spath, however, although the reenactments were of the same character as those used in the exclusionary cases, ${ }^{172}$ the courts permitted the jury to view them. ${ }^{173}$ The next Part of this Comment will argue that with regard to the admission of videotaped reenactments in criminal trials, this change is not necessarily for the better. The logic originally outlined by the Lopez court withstands psychological scrutiny and should be followed as a basis for the continued exclusion of reenactments in criminal trials. The next Part of this Comment will present the basis for excluding prejudicial evidence under the Federal Rules of Evidence.

\section{THE EVIDENTIARY BACKGROUND-RULE 403 AND "UNFAIR PREJUDICE”}

There are numerous ways in which videotaped presentations may be admitted into evidence or presented to a jury, and numerous evidentiary hurdles that videotaped evidence must clear before the court will accept its use. The reenactment may, for example,

repetitive nature. See supra parts I.A-B. Yet, when considered with the prejudice argument in mind, the "unnecessary visualization" argument seems to be another method that accomplishes the same result.

${ }^{170}$ The Trahan court also cites inaccuracy as reason for exclusion. See Trahan, 543 So. 2d at 997. Although this is a common ground for exclusion of any evidence, and particularly for videotaped evidence, see supra note 73 and accompanying text, this Comment does not address this contention.

${ }^{171}$ See supra part II.B.4.

172 See supra part II.B.2-3. Although the videotaped reenactment shown in Mitchell was first prepared on computer and then shown on video, it was arguably more prejudicial than the reenactments discussed in Part II.B. In the exclusionary cases, the reenactments were created in part through the testimony of those who actually were involved in or witnessed the event. In Mitchell, the reenactment was purely speculative, constructed using only the prosecution's version of the facts based on forensic evidence gathered at the scene. The Spath video more closely mirrors traditional reenactments excluded by courts, as it was generated based in part on the testimony of eyewitnesses and forensic evidence.

${ }^{173}$ See supra text accompanying notes 23, 148-50, 159. 
require authentication under Rule $901,{ }^{174}$ may be objected to on hearsay grounds according to Rule $801,{ }^{175}$ or may be introduced to support the testimony of an expert as allowed by Rule 703. ${ }^{176}$ Furthermore, the reenactment must be logically and legally relevant to the issues in dispute. ${ }^{177}$ For purposes of this analysis, it will be assumed that the videotaped reenactment will succeed in satisfying all conditions precedent to an analysis under Federal Rule $403^{178}$ and its analogous state counterparts. ${ }^{179}$

The balancing test of Rule $403^{180}$ is considered the "cornerstone ${ }^{n 181}$ of the Federal Rules, and most evidence that is otherwise

${ }^{174}$ Rule 901(a) provides that " [t]he requirement of authentication or identification as a condition precedent to admissibility is satisfied by evidence sufficient to support a finding that the matter in question is what its proponent claims." FED. R. EvID. 901(a).

${ }^{175}$ The Federal Rules define hearsay as "a statement, other than one made by the declarant while testifying at the trial or hearing, offered in evidence to prove the truth of the matter asserted." FED. R. EvID. 801(c). A statement is defined as "(1) an oral or written assertion or (2) nonverbal conduct of a person, if it is intended by the person as an assertion." FED. R. EVID. 801(a).

${ }^{136}$ Rule 703 provides:

The facts or data in the particular case upon which an expert bases an opinion or inference may be those perceived by or made known to the expert at or before the hearing. If of a type reasonably relied upon by experts in the particular field in forming opinions or inferences upon the subject, the facts or data need not be admissible in evidence.

FED. R. Evid. 703. See also Daubert v. Merrell Dow Pharmaceuticals, Inc., $113 \mathrm{~S}$. Ct. 2786, 2796-98 (1993) (rejecting the "general acceptance" test announced in Frye v. United States, 293 F. 1013 (D.C. Cir. 1923), as superseded by the Federal Rules, which involves a relevance and reliability assessment by the trial judge). For a discussion of the standard that expert testimony must satisfy under the Federal Rules, see Paul C. Giannelli, Forensic Science: Frye, Daubert, and the Federal Rules, 29 CRIM. L. BULl. 428, 430-35 (1993).

${ }^{177}$ Rule 401 defines relevant evidence as that which "ha[s] any tendency to make the existence of any fact that is of consequence to the determination of the action more probable or less probable than it would be without the evidence." FED. R. EVID. 401. Pursuant to Rule 402, "[a]11 relevant evidence is admissible . . . Evidence which is not relevant is not admissible." FED. R. EVID. 402.

${ }^{178}$ Rule 403 provides that relevant evidence "may be excluded if its probative value is substantially outweighed by the danger of unfair prejudice, confusion of the issues, or misleading the jury, or by considerations of undue delay, waste of time, or needless presentation of cumulative evidence." FED. R. EVID. 403.

${ }^{179}$ See infra notes $185-90$ and accompanying text.

180 The balancing test, as it is commonly known, involves weighing probative value against the danger of unfair prejudice and other judicial evils.

${ }^{181}$ Victor J. Gold, Federal Rule of Evidence 403: Observations on the Nature of Unfairly Prejudicial Evidence, 58 WASH. L. REv. 497, 497 (1983) (citing Herbert Peterfreund, Relevance and Its Limits in the Proposed Rules of Evidence for the United States District Courts: Article IV, 25 REC. A.B. CrTY N.Y. 80, 83 (1970)); see also Jon R. Waltz, Judicial Discretion in the Admission of Evidence Under the Federal Rules of Evidence, 
admissible may be analyzed and excluded under its aegis. ${ }^{182}$ One commentator has noted that " [w]ith few exceptions, Rule 403 grants to the trial court the power to exclude evidence that other rules clearly suggest is admissible." ${ }^{183}$ Despite the importance of the rule, courts and commentators have struggled to form a workable definition of "unfair prejudice" that provides the trial judge with a quantifiable guideline according to which the Rule 403 balancing test may be performed. ${ }^{184}$

\section{A. The Breadth of the Federal Rules}

The adoption of the Federal Rules of Evidence by Congress in $1975^{185}$ has had a profound and broad-based impact upon the development of the "law" of evidence. Not only do the rules govern the administration of all civil and criminal trials in federal jurisdictions, ${ }^{186}$ but thirty-five states have enacted or promulgated evidence codes fashioned after the Federal Rules as well. ${ }^{187}$ In those

79 Nw. U. L. REv. 1097, 1110 (1985) ("Rule 403 [is] one of the most, if not the most important of the Federal Rules of Evidence .... .).

${ }^{182}$ See Thomas M. Mengler, The Theory of Discretion in the Federal Rules of Evidence, 74 IOWA L. REV. 413, 441 (1989); see also 22 CHARLES A. WRIGHT \& KENNETH W. Graham, JR., Federal Practice AND Procedure § 5213, at 262-63 (1978) (pointing out that Rule 403 was intended to make every rule of admissibility subject to the power of discretionary exclusion); D. Craig Lewis, Proof and Prejudice: A Constitutional Challenge to the Treatment of Prejudicial Evidence in Federal Criminal Cases, 64 WASH. L. REV. 289, 291 (1989) ("In recognition that the admission of relevant evidence may threaten the reliability of the factfinding process, Rule 403 provides a balancing test by which probative, otherwise admissible evidence may be excluded.").

Mengler argues that "by making most other admissibility rules subordinate to Rule 403, the drafters gave tremendous discretion to the trial court to exclude relevant evidence." Mengler, supra, at 442. But see 1 JACK B. WEINSTEIN \& MARGARET A. BERGER, WEINSTEIN'S EVIDENCE I 403[01], at 403-6 (noting that although courts have extensive power to exclude under Rule 403, trial courts lack the discretion to exclude evidence provided for in Rule 609(a)(2), allowing the admission of evidence of prior crimes or false statements to be used for impeachment purposes).

${ }^{183}$ Mengler, supra note 182, at 441.

18 See infra part III.C.

185 Pub. L. No. 93-595, 88 Stat. 1926 (1975) (codified as amended at 28 U.S.C. app. at 733 (1988 \& Supp. IV 1992)).

${ }^{186}$ See FED. R. EVID. 101.

${ }^{187}$ See, e.g., ALASKA R. EVID. 101-1103; 17A ARIz. REV. STAT. ANN. Rules 101-1103 (1977 \& Supp. 1993); ARK. CODE ANN. \$ 16-41-101 (1987); 7B COLO. REV. STAT. ANN. ch. 33 (West 1980 \& Supp. 1993); DEL. CODE ANN. tit. 17 (1980 \& Supp. 1992); FLA. STAT. ANN. $\S \$ 90.101-.958$ (West 1979 \& Supp. 1994); HAW. REV. STAT. tit. 33, § 6261 (1980 \& Supp. 1992); IDAHO R. Evid. 101-1103; IOWA R. EVID. 101-1103; KY. R. Evid. 101-1104; LA. CODE EvID. ANN. arts. 101-1103 (West 1994); ME. R. EvID. 1011102; MICH. R. EVID. 101-1102; 50 MinN. STAT. ANN. Rules 101-1101 (1980 \& Supp. 1994); MISS R. EvID. 101-1 103; MONT. CODE ANN. § 26, ch. 10, arts. I-X (1993); NEB. 
states that do not have evidentiary codes based upon the federal system, some have individual provisions that mirror the Federal Rules. ${ }^{188}$ In addition, within some of the states not currently adhering to the Federal Rules, there is a strong groundswell of support for their enactment. ${ }^{189}$ Thus, any interpretation based on the Federal Rules will have far-reaching implications for the legal community. ${ }^{190}$

\section{B. The Philosophy of the Federal Rules}

The Federal Rules, according to one commentator, "have brought about a quiet revolution" in the development of the law of evidence. ${ }^{191}$ "[D]iscretion, creativity, and admissibility"-these adjectives are now the hallmarks against which evidentiary questions should be measured. ${ }^{192}$ Flexibility must be built into the Federal

REV. STAT. $\$ \S 27-101$ to $27-1103$ (1989 \& Supp. 1993); NEv. REv. STAT. ANN. $\S \S$ 47.020-56.020 (Michie 1986 \& Supp. 1994); N.H. R. Evid. 100-I 103; N.M. STAT. ANN. (Judicial Pamphlet) \& 11-101 to 11-1102 (Michie 1986 \& Supp. 1993); N.C. GEN. STAT. ch. 8C-1, Rules 101-1102 (1983 \& Supp. 1993); N.D. R. EvID. 101-1103; OHIO Rev. Code ANN. tit. 23 (Anderson 1991 \& Supp. 1992); OKLA. STAT. ANN. tit. 12, $\S \S 2101-3009$ (West 1993 \& Supp. 1994); OR. REV. STAT. ANN. \$§ 40.010-.585 (Butterworth 1988 \& Supp. 1992); R.I. R. Evid. 100-1008; S.D. CoDIFIED LAwS ANN. § 19-1-1 to 19-18-8 (1987 \& Supp. 1993); TENN. R. Evid. 101-1108; TEx. R. CRIM. EVID. 101-1101; UTAH R. EVID. 101-1103; VT. R. EVID. 101-1103; Washington Court Rules Annotated, Rules 101-1103 (1982 \& Supp. 1993); W. VA. R. EVID. 101-1102; WIS. STAT. ANN. §§ 901.01-911.02 (West 1993); WY. R. EvID. 101-1104.

${ }^{188}$ See, e.g., CAL. Evid. CODE $\$ 352$ (West 1966 \& Supp. 1994) (providing judicial discretion to exclude prejudicial evidence, mirroring Federal Rule 403).

${ }^{189}$ See David M. Chuprinsky, Uniform State Code of Evidence in the Works, PA. L.J., May 3, 1993, at 3 (noting that a current proposal in the Pennsylvania State Senate will "create[] a Pennsylvania Code of Evidence . . . based in large part on the Federal Rules of Evidence"); James Hely, Why N.J. Should Adopt Federal Rules of Evidence, 130 N.J. L.J. 99, 99, 111 (1992) (arguing that the adoption of an evidence code based upon the federal rules will "provide judges with helpful interpretations from around the country" in order to "foster the resolution of cases by attenuating the hit and miss nature of trial and by encouraging settlement discussions").

${ }^{190}$ In fact, decisions under the Federal Rules may have implications in non-Federal Rules jurisdictions. See JOSEPH, supra note 41 , 1.02 ("Even in states without codification, the courts frequently look to the Federal Rules for guidance, occasionally going so far as to adopt particular rules as a matter of decisional law." (footnotes omitted)).

${ }^{191}$ Faust F. Rossi, The Silent Revolution, LITIG., Winter 1983, at 13, 13.

${ }^{192}$ Id. Rossi makes this argument by examining the content of the Rules themselves and finding extensive use of discretionary language. Rossi cites, among many, Rules 403 and 609, which provide for the trial judge to weigh the harm of potential evidence against its benefit, as well as Rules 701 and 702, which allow judges to admit expert testimony if they find it "helpful." See id.; see also Gold, supra note 181, at 497 ("Modern evidence law favors admissibility. The Federal Rules of Evidence, for example, eliminate many old exclusionary doctrines while creating an expansive 
Rules to achieve its mandate, which is the "promotion of growth and development of the law of evidence to the end that the truth may be ascertained and proceedings justly determined. ${ }^{193}$ Judicial discretion exists in many forms throughout the course of the Rules, ${ }^{194}$ and its value is underscored by the deferential treatment that evidentiary rulings receive upon appellate review. ${ }^{195}$

definition of relevancy." (footnotes omitted)).

${ }^{193}$ FED. R. EVID. 102: Mengler points out several reasons for the flexibility that is granted to the trial judge under the Rules. See Mengler, supra note 182, at 414-15. Mengler first notes that evidence law "must be simple and accessible," as trial judges are required to make quick, yet often difficult, decisions. Id. at 414 . Next, Mengler points out that every trial is an individual event, each one different from the next, and that "the traditional rules of evidence are imperfect tools in getting at the truth of a particular controversy." Id. Finally, Mengler argues that the decisions that are required "frequently call for a delicate balancing of the probative value of an item of evidence against its prejudicial effect." Id. Thus, Mengler argues that to address the particular needs of the trial and the decisions that a trial judge must contend with on a daily basis, the drafters created a "middle course," so as to "give some guidance, through specific rules, to trial courts and litigants so that the trial process would be sufficiently predictable." Id.

${ }^{194}$ Waltz argues that judicial discretion can be broken down into two general categories-guided and unguided. See Waltz, supra note 181, at 1103 . Guided discretion is provided to the trial judge where he "has some flexibility and choice in decisionmaking but is restrained by more or less specific standards or guidelines to which he visibly must adhere." Id.

Conversely, unguided discretion exists where judicial decision-making is "unhedged by any formal constraints or guidelines and consequently a judge exercising it need never worry that an appellate court will find his ruling in error." Id. Waltz draws these conclusions by examining the occurrence of particular grants of discretion in the Rules. For example, he notes that the auxiliary verb "may," a word signaling discretionary power and choice, "appears thirty-seven times" over the course of the Rules. Id. at 1104. But, unlike Rossi, who concluded that the Rules "bristle" with discretion, see supra notes $191-92$ and accompanying text, Waltz concludes that even though "more evidentiary material is being turned over to the factfinder under the Federal Rules of Evidence than would have been in cases tried at common law," the Rules "are not laced with unprecedented grants of unbridled judicial discretion." Id. at 1118.

${ }^{195}$ See, e.g., United States v. MacDonald, 688 F.2d 224, 227-28 (4th Cir. 1982) (stating that "the appraisal of the probative and prejudicial value of evidence under Rule 403 is entrusted to the sound discretion of the trial judge; absent extraordinary circumstances, the Courts of Appeal will not intervene in its resolution").

According to one study, reversals of the trial judge's decision on evidentiary grounds occur infrequently, if ever at all. See Margaret A. Berger, When, If Ever, Does Evidentiary Error Constitute Reversible Error?, 25 LOY. L.A. L. REV. 893 (1992). Berger, noting that approximately forty thousand civil and criminal cases were tried in the federal courts over a two-year period, found that only thirty cases were decided in which "a court of appeals stated in an officially reported opinion that its reversal was due to an evidentiary error at trial." Id. at 894. In addition to finding that evidentiary reversals rarely occur, Berger concluded that the ratio of reversals in civil and criminal cases is almost identical, see id. at 896 , which is a surprising conclusion in 
Although judicial discretion exists to admit and exclude evidence, the bounds of the Federal Rules are hardly limitless. The Rules categorically exclude certain evidence because of its inherently prejudicial nature, such as the admission of character evidence to prove action in conformity with such character, ${ }^{196}$ and the admission of the alleged victim's past sexual behavior in a rape case. ${ }^{197}$ Finding the use of some evidence detrimental to public welfare, the Rules also exclude evidence for social policy reasons, ${ }^{198}$ such as evidence of subsequent remedial measures, ${ }^{199}$ compromise or offers to compromise, ${ }^{200}$ payment of medical or similar expenses, ${ }^{201}$ pleas, offers to plea, and plea discussions, ${ }^{202}$ as well as the existence of liability insurance. ${ }^{203}$

light of the substantial rights at stake in a criminal trial.

${ }^{196}$ Rule 404(a) provides that “[e]vidence of a person's character or a trait of character is not admissible for the purpose of proving action in conformity therewith on a particular occasion." FED. R. EVID. 404(a). Consistent with the doctrine of limited admissibility, evidence of other crimes, wrongs, or acts may be admissible for corollary purposes, such as "proof of motive, opportunity, intent, preparation, plan, knowledge, identity, or absence of mistake or accident." FED. R. EVID. 404(b). A discussion of limited admissibility is beyond the scope of this Comment, but for an extensive review of the doctrine, see Daniel D. Blinka, Delusion or Despair: The Concept of Limited Admissibility in the Law of Evidence, 39 DEF. L.J. 657 (1990).

${ }^{197}$ Pursuant to Rule 412(a), "in a criminal case in which a person is accused of rape or of assault with intent to commit rape, reputation or opinion evidence of the past sexual behavior of an alleged victim of such rape or assault is not admissible." FED. R. EVID. 412(a).

${ }^{198}$ See FED. R. EVID. 407-411.

${ }^{199}$ Rule 407 provides that if "measures are taken which, if taken previously would have made the event less likely to occur, evidence of the subsequent measures is not admissible to prove negligence or culpable conduct in connection with the event." FED. R. EvID. 407.

${ }^{200}$ Rule 408 excludes "[e]vidence of (1) furnishing or offering . . . to furnish, or (2) accepting or offering ... to accept, a valuable consideration in compromising or attempting to compromise a claim which was disputed as to either validity or amount ... to prove liability for or invalidity of the claim or its amount." FED. R. EVID. 408.

201 Rule 409 excludes "[e]vidence of furnishing or offering . . . to pay medical, hospital, or similar expenses occasioned by an injury . . to prove liability for the injury." FED. R. EvID. 409.

${ }_{202}$ Pursuant to Rule 410, evidence is not admissible against a defendant who makes "(1) a plea of guilty ... later withdrawn; (2) a plea of nolo contendere; (3) any statement made in the course of any proceedings under Rule 11 of the Federal Rules of Criminal Procedure ... ; (4) any statement made in the course of plea discussions ... which do not result in a plea of guilty." FED. R. EvID. 410.

${ }^{203}$ Rule 411 proscribes the admission of "[e]vidence that a person was or was not insured against liability ... upon the issue whether the person acted negligently or otherwise wrongfully." FED. R. Evid. 411. 
Thus, one can argue that because the mandates of the Federal Rules are "discretion," "flexibility," and "admissibility," 204 new forms of evidence and technology, such as advanced videotaped reenactments in criminal trials, ${ }^{205}$ should be welcomed openly and warmly. The Federal Rules, however, frequently exclude both evidence that runs against public policy ${ }^{206}$ and evidence that is inherently prejudicial to a particular litigant. ${ }^{207}$ Professor Graham emphasizes that "any notion that a trial court has discretion to run roughshod over specific rules, and that the law of evidence is simply 'pick an answer' jurisprudence, could not be further from the truth. ${ }^{208}$ Furthermore, the exclusionary policies prescribed by the Federal Rules in the aforementioned instances are complemented by Rule 403 , which grants the trial judge authority to exclude any evidence that is "unfairly prejudicial."

\section{Rule $403^{209}$-Crafting a Definition of "Unfair Prejudice"}

\section{The Rule and Its Intentions}

As the cornerstone of the Federal Rules, ${ }^{210}$ Rule 403 provides the trial judge the ability "to exclude otherwise admissible evidence when the probative value of that evidence is 'substantially outweighed' by, among other things, 'unfair prejudice."'211 By attempting to eliminate unfair prejudice, the Rule strives to accomplish three basic purposes-the avoidance of inferential error, ${ }^{212}$

204 See supra notes $191-95$ and accompanying text.

${ }^{205}$ For examples of the usage of these forms of evidence, see supra part II.B.4.

${ }^{206}$ See supra notes 198-203 and accompanying text.

${ }^{207}$ See supra notes $196-97$ and accompanying text.

${ }^{208}$ MICHAEL H. GRAHAM, MODERN STATE AND FEDERAL EVIDENCE: A COMPREHENSIVE REFERENCE TEXT 8 (1989); see also In re Oil Spill by the Amoco Cadiz off the Coast of France on Mar. 16, 1978, 954 F.2d 1279, 1305 (7th Cir. 1992) (noting that " $[t]$ he Federal Rules of Evidence are statutes, and district judges may not disregard statutes no matter how inconvenient or cumbersome they believe the Rules to be").

${ }^{209}$ See FED. R. EvID. 403; see also supra note 178 for a description of Rule 403.

${ }^{210}$ See supra note 180-84 and accompanying text (describing the importance of Rule 403 in the Federal Rules).

${ }^{211}$ Gold, supra note 181, at 497. One commentator, however, has argued that Rule 403 is unconstitutional as applied to criminal trials and has called for its modification. See Lewis, supra note 182, at 295. Lewis argues that the balancing test should be reversed in criminal trials, calling for the exclusion of relevant evidence unless the court makes a determination that its "probative value substantially outweighs the danger [of unfair prejudice]." Id. at 352.

${ }^{212}$ This is the key prong in analyzing the dangers presented by videotaped reenactments. See infra part III.D. 
the promotion of real fairness in the judicial process, and the realization of economical factfinding. ${ }^{213}$ It can also be argued that the intent of Rule 403 should be considered in conjunction with the goals of Rule $102,{ }^{214}$ which requires a determination of "truth" and a search for "fairness." ${ }^{215}$ At its baseline, "Rule 403's primary focus is whether the jury will use the evidence in a way that will enhance or detract from accurate factfinding. ${ }^{216}$

\section{Balancing and Probative Value}

In conducting a basic Rule 403 analysis, the trial judge must first weigh the "probative value" 217 of the particular piece of evidence

${ }^{213}$ See Andrew K. Dolan, Rule 403: The Prejudice Rule in Evidence, 49 S. CAL. L. REv. 220, 226 (1976). Dolan points out that

[w] hen the prejudice rule is reduced to its components and the intent of each of those components analyzed, these three goals are easily recognizable. The rule's consideration of unfair prejudice, confusion of the issues, and misleading the jury addresses the first two goals, while consideration of undue consumption of time implements the third.

Id.; see also MICHAEL H. GRAHAM, HANDBOOK OF FEDERAL EVIDENCE $\$ 403.1$, at 179 (3d ed. 1991) ("These disadvantages according to Rule 403 consist of unfair prejudice, confusion of the issues, misleading the jury, and considerations of undue delay, waste of time and the needless presentation of cumulative evidence.").

${ }^{214}$ See supra note 193 and accompanying text.

215 See Victor J. Gold, Limiting Judicial Discretion to Exclude Prejudicial Evidence, 18 U.C. DAVIS L. REV. 59, 65 (1984). Gold notes that Rule 403 is subservient to the more basic goal of Rule 102, which is "the ascertainment of truth in a context of procedural fairness." Id. Gold also points out that "courts and commentators recognize that Rule 102 identifies the policies that should control the exercise of discretion under Rule 403." Id. at 65 n.18.

${ }^{216} \mathrm{Id}$. at 67.

${ }^{217}$ Commentators differ on an exact definition of probative value. Dolan notes that probative value is a "relative concept." Dolan, supra note 213, at 233. As such, determining the probative value of a piece of evidence "involves a measurement of the degree to which the evidence persuades the trier of fact that the particular fact exists and the distance of the particular fact from the ultimate issues of the case." Id. Probative value increases as the evidence moves closer to proving or disproving an ultimate fact or issue in dispute. See id. Conversely, probative value decreases as the number of inferences that must be drawn in the logical chain increases. See id.

Lewis provides a less theoretical definition, observing that commentators often disagree over how probative value should be assessed. See Lewis, supra note 182, at 315. Lewis defines probative value as "a measure of the extent to which evidence may contribute to a more accurate factual determination" and notes that the "admission of probative evidence ... always enhanc[es] accurate factfinding, and its exclusion ... invariably detract[s] from accuracy." Id. Gold advocates a contextual approach to defining probative value and argues it should be defined "as a product of the logical potential of evidence in the evidentiary and cognitive context within which it is offered." Gold, supra note 215 , at 76. 
against its "potential to inflict unfair prejudice." 218 Upon balancing the two factors, the trial court must then determine if the probative value is substantially outweighed by unfair prejudice. ${ }^{219}$ If the trial court reaches that conclusion, it may exclude the evidence. ${ }^{220}$ The trial judge's decision to exclude or include evidence has been given substantial deference by reviewing panels. ${ }^{221}$ One leading commentator stresses the difficulty in accomplishing this act of balancing: "Analyzing and weighing the pertinent costs and benefits is no trivial task[, and w]ise judges may come to differing conclusions in similar situations." ${ }^{222}$

${ }^{218}$ Gold, supra note 215 , at 64 . As the focus of this Comment is the unfair prejudice created by the use of videotaped reenactments, the other dangers articulated by Rule 403-confusion of the issues and misleading the jury-can be grouped into an "unfair prejudice" analysis and will not be discussed in detail.

${ }^{219}$ See GrAHAM, supra note $213, \S 403.1$, at 179 ("Evidence which is relevant is to be excluded only if its probative value is substantially outweighed by any of [the Rule 403] factors alone or in combination."); Gold, supra note 215, at 64 ("If the danger of unfair prejudice 'substantially outweighs' probative value, the court has discretion to exclude the evidence.").

${ }^{220}$ When excluding evidence under Rule 403 , courts frequently fail to conduct the requisite balancing test. See Gold, supra note 181, at 502 ("Absent a coherent theory of unfair prejudice, trial courts cannot meaningfully evaluate evidence on or off the record for the presence of unfair prejudice, nor can they conduct the required balancing test."). Gold points out that a "distressingly large number of cases purporting to apply Rule $\mathbf{4 0 3}$ conclude that evidence is or is not unfairly prejudicial without explaining why or even attempting to define unfair prejudice." Id. at 500 . Furthermore, Gold notes, somewhat incredulously, that "[s]till more cases utterly fail to conduct the required balancing test or, while purporting to balance, give no hint as to how or why a particular balance was struck." Id. at 500-01 (footnotes omitted); see also United States v. Fleming, 594 F.2d 598, 607-08 (7th Cir.), cert. denied, 442 U.S. 93 (1979) (finding no abuse of discretion and ascribing a reason to trial court's admission of photographs of victim's nude and bound body); MCCORMICK ON EvidENCE 547 (Edward W. Cleary ed., 3d ed. 1984 \& Supp. 1987) ("Nevertheless, discretion can be abused, and some appellate courts have urged trial courts to articulate the reasoning behind their relevance rulings." (footnotes omitted)).

221 See MCCORMICK ON EVIDENCE, supra note 220, at 546-47 (stating that "much leeway is given to trial judges who must fairly weigh probative value against probable dangers" (footnotes omitted)); see also United States v. Derring, 592 F.2d 1003, 1007 n.6 (8th Cir. 1979) ("'[T]he task of balancing the probative value of the evidence against its purely prejudicial effect is primarily one for the trial court. And if the trial judge in the exercise of his discretion determines that the evidence should be admitted, we normally defer to his judgment." (quoting Unites States v. Hall, 565 F.2d 1052, 1055 (8th Cir. 1977))); United States v. Schiff, 612 F.2d 73, 80 (2d Cir. 1979) ("The balancing process required by Rule 403 is entrusted, in the first instance, to the trial judge, . . . and we have held that the trial judge's discretion should not be disturbed lightly.").

${ }^{222}$ MCCORMICK ON EVIDENCE, supra note 220, at 546. 


\section{Defining Unfair Prejudice}

Although a measurement of unfair prejudice is essential to issuing a Rule 403 decision, courts and commentators have struggled to find a quantifiable definition. ${ }^{223}$ Generally, all evidence presented by an opposing party is in some way "prejudicial"; therefore, prejudice "does not simply mean damage to the opponent's cause." ${ }^{224}$ The Advisory Committee's Notes to Rule 403 provide some guidance in suggesting that the use of emotion in decision-making is a relevant consideration, though not necessarily the only consideration in measuring unfair prejudice. ${ }^{225}$ On the other hand, the use of logical reasoning should not be seen as the key to rational decision-making, because logical flaws abound; ${ }^{226}$

${ }^{223}$ One commentator notes that a definition of unfair prejudice is comparable to Justice Stewart's oft-quoted definition of obscenity, in which the Justice characterized obscenity as undefinable but claimed, "I know it when I see it." Dolan, supra note 213, at 238 (quoting Jacobellis v. Ohio, 378 U.S. 184, 197 (1964) (Stewart, J., concurring)).

${ }_{224}$ MCCORMICK ON EVIDENCE, supra note 220, at 545; see, e.g., Real v. Hogan, 828 F.2d 58, 64 (1st Cir. 1987) ("The law protects not against prejudice, but against unfair prejudice."); Crawford v. Edmonson, 764 F.2d 479, 484 (7th Cir.), cert. denied, 474 U.S. 905 (1985) ("Since most evidence presented by one party in litigation will presumably be prejudicial to the other, in the sense that it favors the party introducing it and damages the opposing party's case, Rule 403 requires that the evidence sought to be excluded threaten unfair prejudice."); United States v. Monahan, 633 F.2d 984, 985 (1st Cir. 1980) ("Rule 403 is not contravened by evidence that might show only that the defendant is guilty of the crime charged.").

${ }^{225}$ See FED. R. EvID. 403 advisory committee's note ('Unfair prejudice' within its context means an undue tendency to suggest decision on an improper basis, commonly, though not necessarily, an emotional one."); see also United States v. Skillman, 922 F.2d 1370, 1374 (9th Cir. 1991) (adopting the Advisory Committee's suggestion in its definition of unfair prejudice).

The notion that emotional decision-making is necessarily detrimental to accurate factfinding is disputed, however, and it is argued that the introduction of emotion into the trial process has beneficial effects:

Equating emotion with prejudice is a mistake. While emotion can be an improper basis for a judgment, it can also have an acceptable, and even vital role in reaching an accurate and fair decision. It is both unrealistic and undesirable to expect a jury not to react emotionally to much of what goes on in a courtroom. ... . In fact, the ability of twelve laypersons to interject human sensibilities into a proceeding otherwise dominated by the cold logic of the law arguably embodies the true worth of the jury system.

Gold, supra note 181, at 504.

${ }^{226}$ Gold argues that "logic is not a talisman against inaccuracy and unfairness." Gold, supra note $\mathbf{2 1 5}$, at $\mathbf{8 0}$. Unfair prejudice resulting from the use of logic can occur when the logic is derived from improper premises. If a juror believes the saying "once a thief, always a thief" is true, then the introduction of the defendant's prior criminal record "will logically lead to the conclusion that the defendant is 
courts have found unfair prejudice in a variety of situations. ${ }^{227}$

It has been argued that the most compelling and workable definition of unfair prejudice is advanced by Professor Gold, who quantifies evidence as unfairly prejudicial when it detracts from the accuracy of factfinding by inducing the jury to commit an inferential error. ${ }^{228}$ Another commentator asserts that the commission of

guilty." Id. Therefore, because the premise from which the logic was derived is incorrect, "the evidence giving effect to the premise through the process of logic leads to inaccuracy and unfairness." Id.

Gold also cites a poignant example of how logic can generate inaccurate inferences when derived from improper premises, stating that " $[t]$ he extermination of European Jewry in World War II was, at least in part, the product of a ruthlessly logical and unemotional bureaucracy operating under horrific premises." Gold, supra note 181, at 505 n.38 (citing HANNAH ARENDT, EICHMANN IN JERUSALEM: A REPORT ON THE BANALITY OF EVIL (1965)).

${ }^{227}$ Lewis points out that the unfair prejudice may "demonstrate a defendant's unsavory or immoral character, or unpopular or contemptible associations or beliefs that could arouse juror antagonism; it may vividly portray . . . offensive aspects of the charged crime . . . or overemphasize negative connotations, inciting a jury's vindictiveness." Lewis, supra note 182, at 321 (footnotes omitted). See United States v. Williams, 957 F.2d 1238, 1244 (5th Cir. 1992) (finding harmless error in admitting evidence that a marijuana cigarette was found on defendant at time of arrest in a prosecution for possession with intent to distribute cocaine); United States v. LehderRivas, 955 F.2d 1510, 1516-17 (11th Cir.) (harmless error in admitting evidence of defendant's prior deportation, transportation of prostitutes, drug use, excessive partying and fathering an illegitimate child, in a prosecution for conspiracy to import cocaine), cert. denied, 113 S. Ct. 347 (1992); United States v. Hill, 953 F.2d 452, 456 (9th Cir. 1991) (error in allowing defendant's former girlfriend to testify that she and the defendants had used cocaine together in a conspiracy and cocaine distribution prosecution); United States v. Columbo, 909 F.2d 711, 713-15 (2d Cir. 1990) (error in admitting evidence that the victim had been raped and sodomized by defendant's co-conspirator in a prosecution for conspiracy to violate RICO and to distribute narcotics); United States v. Rhodes, 886 F.2d 375, 378-81 (D.C. Cir. 1989) (error in admitting fraudulent checks that had not been connected to the defendant in a prosecution for the presentment of a fraudulent check); United States v. Miller, 874 F.2d 1255, 1268-69 (9th Cir. 1989) (error in admitting evidence that defendant FBI agent had previously sold Department of Motor Vehicles records to an FBI informant in a prosecution for bribery and conspiracy to commit espionage).

But some commentators argue that judges are unable to detect and predict what type of evidence is in fact prejudicial. See Lee E. Teitelbaum et al., Evaluating the Prejudicial Effect of Evidence: Can Judges Identify the Impact of Improper Evidence on Juries?, 1983 WIS. L. REV. 1147 (conducting an empirical study using "[m]embers of the community, the bar, and the bench" to determine the prejudicial effect of different evidentiary items in the context of a summarized trial). But see Gold, supra note 215, at $61 \mathrm{n.5}$ (questioning the assumptions underlying the findings of Teitelbaum et al.); Dale A. Nance, The Best Evidence Principle, 73 IowA L. REv. 227, $291 \mathrm{n.306}$ (1988) (calling the Teitelbaum et al. study "suggestive, if poorly constructed"); Waltz, supra note 181, at $1110 \mathrm{n} .72$ (arguing that the Teitelbaum et al. study is based upon "suspect empirical data").

${ }^{228}$ See Gold, supra note 215, at 84. Lewis notes that Professor Gold's analysis 
inferential error is worse than jury "confusion" and may "mislead the trier of fact if he is not properly equipped to judge the probative worth of the evidence." 229

Inferential error, Gold argues, "occurs when the jury incorrectly decides that evidence is probative of an alleged fact or event, ${ }^{230}$ when it is in fact not probative of that particular fact. The use of evidence of damage to prove liability typically falls within this category of inferential error. ${ }^{231}$ In this situation, evidence of

"presents a useful basis for evaluating the balancing test of Rule 403 , because it demonstrates that probative value and prejudice are not 'apples and oranges' but rather 'apples and anti-apples,' positive and negative contributors to the search for reliability in factfinding." Lewis, supra note 182, at 307; see also Victor J. Gold, Jury Wobble: Judicial Tolerance of Jury Inferential Error, 59 S. CAL. L. REv. 391, 392 (1986) [hereinafter Gold, Jury Wobble] (noting that juries are forced to deliberate "based on illogic or bias rather than proper decision-making inputs").

Numerous other authorities have found this definition of unfair prejudice to be particularly workable. See United States v. Currier, 836 F.2d 11, 18 (1st Cir. 1987) (citing Gold, Jury Wobble, supra, and arguing that "[u]nfairly prejudicial evidence is evidence having some quality that moves the jury to attribute to it excessive probative value"); Lockwood v. A C \& S, Inc., 722 P.2d 826, 839 (Wash. Ct. App. 1986) (examining various methods of determining unfair prejudice and stating that "unfair prejudice may exist where evidence is admitted which distorts the truth but which cannot be effectively rebutted or clarified" (citing Gold, Jury Wobble, supra)); State v. DeSantis, 456 N.W.2d 600, 608 (Wis. 1990) (citing Gold, Jury Wobble, supra, for a discussion of Rule 403 and noting that "[e]vidence is unduly prejudicial when it threatens the fundamental goals of accuracy and fairness of the trial by misleading the jury or by influencing the jury to decide the case upon an improper basis; State v. Rutchik, 341 N.W.2d 639, 655 (Wis. 1984) (Abrahamson, J., dissenting) (noting that evidence of other crimes causes unfair prejudice because it "may have so dominated the minds of the jurors that the jurors exaggerated its probativeness, gave the other crime evidence undue weight, and paid less heed to other probative evidence," and noting that unfair prejudice is "a phrase rarely defined by the courts" and that Gold, Jury Wobble, supra, should be consulted for discussion); Thomas M. Mengler, An Application of the Prejudice Rule in Evidence: People v. Hendricks, 1991 U. ILL. L. REV. 507, 521-23 (arguing that there are "[n]o guidelines" for an application of Rule 403 and that "Gold's definition seems accurate as far as it goes; indeed, it may be slightly better than [the] articulation [in the advisory notes]"); Robert G. Miceli, Deprivation of Due Process for Physicians: The "Failure to Diagnose" Cause of Action, 33 ST. LOUIS U. L.J. 859, 907 (1989) (noting that Rule 403 was designed to prevent "[m]isleading evidence [that] may be given too much weight by the jury because it is 'seductively persuasive" and adopting Gold's definition of inferential error in quantifying Rule 403); J. Alexander Tanford, A Political-Choice Approach to Limiting Prejudicial Evidence, 64 IND. L.J. 831, 844 (1989) ("The second common meaning given to prejudice is interference with the truth-seeking process. Evidence is said to be prejudicial if it confuses the issues, confuses or misleads the jury, diverts or distracts the jury from the facts, or causes the jurors to make inferential errors." (footnotes omitted)).

${ }^{229}$ MCCORMICK ON EVIDENCE, supra note 220, at 546.

${ }^{230}$ Gold, supra note 181 , at 506 .

${ }^{231}$ See id. 
damage is not probative of fault or liability, but by using the spectacle of plaintiff's injuries to show negligence, prejudice will occur "not because the jury has been emotionally moved by the evidence, but because the evidence has induced an inferential error." 232

Inferential error, and hence unfair prejudice, may also occur when the jury decides "that evidence is more or less probative of a fact or event than it is. ${ }^{233}$ In defining this form of inferential error, Gold notes that

the prejudicial impact of photographs of a victim's gory remains derives from the potential such vivid evidence has to so dominate the minds of jurors that they exaggerate its probativeness. The fact that the evidence of this type may evoke an emotional reaction from the jury does not necessarily make it prejudicial. There may be nothing wrong with shocking a jury with the repulsiveness of a crime, as long as the impression made by the evidence in question is commensurate with its probative worth. ${ }^{234}$

Professor Imwinkelried offers an analysis of Gold's concerns with inferential error, in noting that

the juror ideally should ascribe to an item of evidence only the probative value that the item deserves. Suppose, however, that the judge believes that...the jury is likely to misestimate and overvalue the probative worth of the item. The judge may fear that the jury will draw a stronger inference than is warranted from the evidence. Giving the item undue weight would constitute an inferential error. ${ }^{235}$

The dangers of inferential error are particularly profound because the error is often "subtle," occurring "when the jury diligently pursues the issues it is charged with deciding." Inferential error becomes "unfairly prejudicial" when opposing counsel is unable to expose the error or otherwise negate its

232 Id.

${ }^{233} I d$.

${ }^{234}$ Id. This Comment is primarily concerned with this type of error, as the use of a videotaped reenactment will have such a profound impact upon the minds of jurors that they will overvalue its probative worth. See infra part III.D.

${ }^{235}$ Edward J. Imwinkelried, The Meaning of Probative Value and Prejudice in Federal Rule of Evidence 403: Can Rule 403 Be Used to Resurrect the Common Law of Evidence, 41 VAND. L. REV. 879, 895 (1988) (citations omitted).

${ }^{236}$ Gold, supra note 181 , at 507 . The admission of scientific evidence often falls into this category of error, as "it is widely assumed that lay jurors overestimate the objectivity and certainty of scientific testimony." Imwinkelried, supra note 235, at 895. 
harmful effects. ${ }^{237}$ Exposing this form of error is a difficult, if not impossible task, because the inferential error often "distorts the truth in such a subtle way that its dangers cannot be explained to the jury. ${ }^{238}$ Defining when and how inferential error occurs, however, is a substantial undertaking.

\section{E. Inferential Error and Judgmental Heuristics}

Defining unfair prejudice as that evidence which causes the trier of fact to commit inferential error is the first step in determining whether evidence is, in fact, unfairly prejudicial under Rule 403. The next step in the analysis is to determine which cognitive processes tend to cause inferential error. This requires an examination of certain cognitive learning tools ${ }^{239}$ and an application of these concepts to a jury's viewing of a videotaped reenactment.

Individuals process, comprehend, and react to large quantities of information each day. In order to accomplish this monumental task, individuals rely on "judgmental heuristics" 240 to reduce complex inferential tasks to simple judgmental operations. ${ }^{241}$ Heuristics are "cognitive simplifying strategies used to reduce the complexity of information that must be considered in making a decision. "242 Through the use of heuristics, individuals are able to sort through the mass of information they acquire each day and make appropriate classifications and determinations. Without heuristics, or cognitive "rules of thumb," individuals would feel inclined to make a detailed analysis of each and every decision. ${ }^{243}$ Although in some instances the benefit of such an analysis may outweigh the associated costs, such as in the case of buying a car or a house, in other instances, such as deciding which shirt to wear in

${ }^{237}$ Gold, supra note 181 , at 508.

238 Id.

${ }^{239}$ See RICHARD NiSBetT \& LEe Ross, Human INFERENCE: STRATEGIES AND SHORTCOMINGS OF SOCIAL JUDGMENT 17-62 (1980) (discussing judgmental heuristics and knowledge structures); Ward Edwards \& Detlef Von Winterfeldt, Cognitive Illusions and Their Implications for the Law, 59 S. CAL. L. REv. 225, 235-37 (1986); Gold, supra note 181, at 511-24 (discussing heuristics, knowledge structures, and Rule 403).

240 "Judgmental heuristics" can be splintered into two more specific categories-the "representative heuristic," see infra part III.D.1., and the "availability heuristic," see infra part III.D.2; see also NISBETT \& Ross, supra note 239, at 7-8.

${ }^{241}$ See NISBETT \& ROSS, supra note 239 , at 7.

${ }^{242}$ Gold, supra note 181 , at 511.

${ }^{243}$ See id. 
the morning or what to eat for dinner, a complex study of the relative merits of the issue may not be worth the undertaking.

Heuristics, however, are not infallible. ${ }^{244}$ While heuristics may serve to simplify available data, they "sometimes direct our attention toward vivid, anecdotal information which may be misleading, and away from more pallid, complex evidence which may be highly probative. ${ }^{245}$ The inferential error that heuristics may cause can be illustrated through the use of the following example concerning tree identification. In determining whether to classify a particular plant as a tree or a bush,

a decisionmaker may wish to avoid a systematic study of the subject plant and the science of botany in favor of a quick search of the plant's most salient characteristics. These characteristics can then be compared to presumed characteristics of trees and bushes. ... [A] decisionmaker may classify the plant as a bush if it appears mature yet is only two feet high. ... [T] his strategy, while effective in many cases ... might lead to inferential error if the decisionmaker were unfamiliar with bonsai trees. ${ }^{246}$

When this mental phenomenon occurs, inferential error may follow.

\section{The Representative Heuristic}

Individuals frequently rely on judgments and assessments, as evidenced by the bonsai tree example. ${ }^{247}$ Use of the "representative heuristic" permits individuals to reduce the chore of analyzing information or events and their relationship to a series of simple similarity judgments. Thus, individuals assign objects to one particular conceptual category rather than another "according to the extent to which its principal features represent or resemble one category more than another." ${ }^{248}$ The bonsai tree was misidentified as a bush because the representative heuristic caused an examination of the size of the plant and, based on a comparison with similar-sized plants, determined that the tree was actually a bush.

${ }^{241}$ See id.

245 Id.

${ }^{246} I d$. at 509.

${ }^{247}$ See supra note 246 and accompanying text.

${ }^{248}$ NisBetT \& Ross, supra note 239 , at 7. 
The representative heuristic performs many cognitive functions. ${ }^{249}$ The heuristic is employed when a decision-maker is given a result and asked to "infer the process by which that result was generated." Whon this cognitive task is performed, the heuristic will often suggest that the process is in some manner similar to the result it has subsequently produced. ${ }^{251}$ Inferential error may therefore occur, as the result may be in no way related to the generating process and "salient features of objects or events ... are not ... accurate indicators of the relationship between them. ${ }^{n 252}$

The representative heuristic also allows individuals to infer generalizations concerning a large body of data from a limited sample. Individuals " $u s[e]$ the data at hand to make inferences about the general characteristics ... of the population from which those data were drawn. ${ }^{253}$ Applying this heuristic would enable an individual to determine what the United States is like as a country by visiting several towns and speaking with several people. ${ }^{254}$ Although the heuristic might be helpful in making generalizations, the potential to commit inferential error is strong, because the selection of small bits of data from a vast sample may lead to a conclusion based on unrepresentative examples. ${ }^{255}$

Gold points out the potential danger of relying upon the heuristic for this purpose, noting that "people are often insensitive to the amount of evidence they consider and tend to be swayed by a small amount of vivid, anecdotal evidence. ${ }^{256}$ In arguing that

${ }^{249}$ See Gold, supra note 181, at 511-16.

250 Id. at 512.

251 In this situation, the heuristic will infer that destructive results had culpable antecedents and that benign results had benign antecedents. Gold notes that decision-makers often find an individual more at fault where, after she allows her car to roll down a hill, it ends up striking a person as opposed to a fire hydrant. See id.

${ }^{252} \mathrm{Id}$. at 512.

253 NISBETT \& Ross, supra note 239 , at 77 ; see also id. at $77-82$ (discussing problems of generalizations insensitive to sample size).

${ }^{254}$ See id. at 77.

${ }^{255}$ See id. at 77-82 (describing the errors caused by evaluating small statistical samples).

${ }^{256}$ Gold, supra note 181 , at 515 . Nisbett and Ross use the following example to illustrate the effect of an individual's susceptibility to make decisions based upon small amounts of vivid, concrete information: In a course selection situation for introductory college students, subjects were given mean course evaluations (on a standard scale) and were told that the results were generated from questioning "dozens of previous students." See NisBeTt \& Ross, supra note 239, at 79. Subjects then were allowed to speak personally with two or three students who evaluated the courses and provided comments. See $i d$. The results of the study indicated that the "abstract, large-sample" review had much less of an impact on course decisions than 
the inferential error caused by the representative heuristic may be substantial, Gold postulates:

Candidates often capitalize upon this tendency in political debate, where the wisdom of social programs is "established" not by reference to the mass of data demonstrating their value, but by reference to an absurdly small number of colorful case histories. The representativeness heuristic permits voters to infer incorrectly that, since the case histories have been taken from a larger mass of data, those histories must be representative of the mass. ${ }^{257}$

Applying this logic to the courtroom, the heuristic would cause jurors to commit inferential error, because vivid individual examples, such as the case of social program successes, tend to distract attention from a considerable amount of relevant evidence that is more representative of the whole. ${ }^{258}$ Pratkanis and Aronson conclude that "[a]ll other things being equal, most people are more deeply influenced by one clear, vivid, personal example than by an abundance of statistical data. ${ }^{\text {259 }}$ Reliance upon the representative heuristic, therefore, creates a substantial possibility of inferential error when a videotaped reenactment is introduced, because it presents the potential to dwarf other more probative, yet less vivid, testimony and evidence. ${ }^{260}$

did the small quantities of personal, concrete, and vivid suggestions. Id.

Another example of this effect can be seen when a consumer is in the market for a car. The consumer wants a reliable, durable automobile, without regard for speed, flashiness, or attractiveness. After researching the relevant market data that has sampled thousands of car owners for reliability and durability, the purchaser decides to buy a Toyota. The day before going to the dealership, the purchaser runs into an old friend and informs her of the impending purchase. Upon hearing this, the friend relates that she once owned a Toyota and that it was in the shop once a month, that parts fell off while she was driving, and that she was afraid to drive it for fear of what would happen next. As a result of this information, the purchaser puts her decision to buy a Toyota on hold. See ANTHONY R. Pratkanis \& Elliot ARONSON, Ace of PROPAGaNdA: The Everyday USE AND ABUSE OF PERSUASION 130 (1991).

${ }^{257}$ Gold, supra note 181, at 515. Ronald Reagan, dubbed "The Great Communicator, "frequently implicated this cognitive strategy by pointing to individual achievements to dramatize the success of his policies. See PRATKANIS \& ARONSON, supra note 256, at 130-33.

${ }^{258}$ See Gold, supra note 181, at 515.

${ }^{259}$ PRATKANIS \& ARONSON, supra note 256, at 130.

${ }^{260}$ See infra part III.F.1. The Hopperstad court expressed concern with the effects of the representative heuristic, commenting that "[s]eeing the events depicted exactly as the State's witnesses said they happened is bound to affect the jury out of all proportion to its value as evidence." State v. Hopperstad, 367 N.W.2d 546, 549 (Minn. Ct. App. 1985). 


\section{The Availability Heuristic}

When making a decision, individuals must sort through all data that is stored in their memory. But which source or piece of information should the individual rely upon in making a mundane or difficult daily decision? The availability heuristic is a cognitive device that assists individuals in "simplify[ing] the process of choosing data used in making a decision." 261 The heuristic dictates that in making a decision, individuals are influenced by the relative cognitive "availability" of a particular piece of data and "[w]hen people are required to judge . . . the likelihood of particular events, they often may be influenced by the relative availability of the objects or events, that is, their accessibility in the processes of perception, memory, or construction from imagination. ${ }^{262}$

The data to be used for the decision, therefore, will be the data which is "most available to the decisionmaker's perceptions, memory and imagination." 263 The functioning of the availability heuristic can be illustrated by the commuter who wishes to determine the probability that the morning train will reach the station by eight o'clock in the morning. The commuter may

reliably base his prediction on a timetable listing an 8 A.M. arrival. Often, however, there are many factors unrelated to probability that can influence availability. If the commuter has not previously traveled on the train in question, the fact that this train has never ... been on time may be unavailable to him. Thus the availability heuristic ... may cause the decisionmaker to rely on data of little or no probative value. If, in relying on a timetable, the commuter neglects to check its reliability with [a] veteran of public transportation standing on the platform ... then using the availability heuristic has . . . caused him to ignore the most reliable evidence. ${ }^{264}$

There are numerous factors, however, that cause information to become "available" to an individual, or to a jury, that are independent of probative value and which will cause inferential error. ${ }^{265}$

${ }^{261}$ Gold, supra note 181 , at 516.

${ }^{262}$ NISBETT \& Ross, supra note 239, at 18.

${ }^{263}$ Gold, supra note 181 , at 516.

261 Id.

265 See NISBETT \& ROSS, supra note 239, at 43-62 (discussing the impact of vividness on inferential error); Gold, supra note 181, at 516 (stating that "there are many factors unrelated to probability that can influence availability"). 


\section{a. What Causes Data to Become "Available"?}

Data that is "available," according to the availability heuristic, is data which is likely to be called upon in decision-making. Nisbett and Ross have determined that "inferential weight," and hence availability, is given to data in proportion to that information's "salience and vividness." Information that is vivid, the logical syllogism dictates, is information that is deemed available and is therefore summarily used in decision-making. ${ }^{267}$ Thus, although vivid data or evidence is not necessarily the most probative data or evidence, it is the information most likely to enter the inferential stream first and be given decision-making preference. ${ }^{268}$ The use of this "evidential weighing" is dangerous, Nisbett and Ross conclude, because "the vividness of information is normally related only obliquely at best to its true value as evidence." ${ }^{269}$

Because vividness is the key to availability, determining "[w]hat makes evidence vivid is ... central to determining what makes evidence prejudicial." "Vividness" has several definitions in the cognitive context that are unrelated to its everyday meaning. ${ }^{271}$ Evidence becomes vivid, and thus likely to attract and keep a juror's

${ }^{266}$ NISBETT \& ROSS, supra note 239, at 8 ("Information is heeded, processed, stored, and retrieved in proportion to its sensory, cognitive, and affective salience.").

${ }^{267}$ See $i d .\left({ }^{\text {a }}[\mathrm{M}]\right.$ ore vivid information is more likely to enter inferential processes than is less vivid information.").

${ }^{263}$ See id.; see also Gold, supra note 181, at 518 . ("Evidence which, because of its vividness, is selected by the availability heuristic to influence a decision presents a danger of inferential error because vividness is normally only vaguely related to probativeness.").

Aside from vividness, there are several other factors that cause information to be recalled in a manner unrelated to its probative value. Information presented to the decision-maker first, or "first impressions," frequently has an "undue influence on final judgment." NISBETT \& ROSS, supra note 239, at 172. This psychological occurrence is known as the "primacy effect in impression formation." Id. As a result of this, Gold suggests that "the order in which evidence is presented to the jury can affect its memorability and thus its availability in subsequent decisionmaking." Gold, supra note 181, at 517. In addition, early-encountered evidence serves as "raw material for inferences about what the object is like." NISBETr \& Ross, supra note 239 , at 172 . Thus, the primacy effect may impact the formation of ideas concerning all subsequent evidence.

In direct contrast to the primacy effect, but having similar results, is information presented shortly prior to decision-making. See id. But "recency effects" do not occur nearly as frequently as do "primacy effects" and require the presence of other factors as well. See id.

${ }^{269}$ NISBETT \& Ross, supra note 239 , at 8.

${ }^{270}$ Gold, supra note 181 , at 518.

${ }^{271}$ See NISBETT \& ROSS, supra note 239, at 43-62 (discussing the impact of vividness on inferential weighting). 
attention, when it is "emotionally interesting," "272 "concrete and imagery-provoking," ${ }^{273}$ and "proximate in a sensory, temporal, or spatial way." 274 "Concrete and imagery-provoking" vividness is central to the inferential error that occurs when videotaped reenactments are viewed by the jury. ${ }^{275}$

\section{b. Concrete and Imagery-Provoking Vividness}

When evidence promotes the "imaginability" or "sensory imagery" of the event in dispute, it is more likely to be vivid. ${ }^{276}$ Vivid information attracts attention, makes the information seem more concrete and personal, and most importantly, makes information more memorable. ${ }^{277}$ Informing the jury that the victim died of fatal injuries suffered in a car accident is less likely to provoke a vivid response in the jury's mind than is informing them that the victim was killed when run over by an eighteen-wheel truck that flattened the car and crushed the driver's skull. ${ }^{278}$ The effect on the jury in this situation should be clear. In the latter description, the jury's instincts of concern and outrage could lead to a desire to punish the wrongdoer or to impose compensatory damages for such grievous bodily injury. As a result of the former description, a juror's response may more likely be "well, accidents happen." 279

${ }^{272}$ Id. at 45. Emotional interest occurs in jurors when events involve people they know, when events involve people about whom they have strong feelings, and when events affect the jurors' "needs, desires, motives, and values." Id. at 46 . Gold describes emotional interest as that which is "relevant to the jury in some personal way." Gold, supra note 181, at 518 (footnote omitted). As a result, courts generally exclude jurors with some relation to the parties, and attorneys often strike those jurors who they believe will have biases favoring the opposing party. See id. (noting that "when the parties to, or subject matter of, a lawsuit are familiar to a prospective juror, her emotional involvement is obvious and may even be grounds for disqualification").

273 NISBETT \& ROSS, supra note 239 , at 45.

${ }^{274} I d$. at 45, 49-51. This form of vividness concerns how the data or evidence relates to the juror. Thus, the knowledge that a bank was robbed in a juror's neighborhood today is much more "vivid" than the knowledge that a bank was robbed in a cross-town neighborhood last week. News of the neighborhood bank robbery will likely have a greater impact on a juror's impulse to punish than will news of the crosstown heist. See id. at 49-50.

275 See infra part III.D.2.b.

${ }^{276}$ NISBETT \& ROSS, supra note 239 , at 47.

277 See PRATKANIS \& ARONSON, supra note 256, at 129.

${ }^{278}$ See NiSBETT \& Ross, supra note 239 , at 47.

${ }^{279}$ See id. 
Similarly, the description "'p]laintiff was severely injured' is not likely to have nearly the impact of '[b]lood was gushing from the knife wounds in plaintiff's back." 280 Thus, although both forms of the testimony relate to the same event, the latter description is more vivid, and thereby will have more of an impact on the decision-making process. Yet vividness bears no relation to actual liability or culpability and is likely to cause inferential error if used as the primary source of information for decision-making.

\section{c. The Impact of Vivid Evidence}

Vivid information, which is concrete and image-provoking, affects inferential processes through memory because it is more readily retained and more quickly recalled. ${ }^{281}$ By impacting memory in this manner, vivid information is likely to be "more available for decisionmaking and more likely to be accepted as representative of the objects or events it describes than is pallid evidence. ${ }^{\text {282 }}$ Nisbett and Ross conclude: "Since more memorable information is ... more available for incorporation into inferences, ... the assumption [is] that firsthand, sensory information, and even secondhand information if it is concrete and imageryprovoking, will have more effect on inferences that occur at some temporal remove than more pallid and abstract information will have." ${ }^{283}$

What are the implications of the availability heuristic and the enhanced recall of vivid evidence? In some situations, vivid evidence may be highly probative of material issues in dispute, and its impact on decision-making will be approximately equal to its probative value. ${ }^{284}$ The dangers posed by vivid evidence occur when that evidence's vividness exceeds its objective probative value. When

${ }^{280}$ Gold, supra note 181 , at 519.

281 See NISBETT \& Ross, supra note 239, at 51.

${ }^{282}$ Gold, supra note 181 , at 519 . The elevation in importance of memorable information can also be attributed in part to the trial itself, for "in the midst of a trial that is likely to produce many dull patches in the form of soporific depositions, uninspired testimony, and dimly comprehended exchanges between judge and counsel, jurors love to be entertained." Philip K. Anthony \& Donald E. Vinson, Demonstrative Exhibits: A Key to Effective Jury Presentations, FOR THE DEFENSE, Nov. 1986 , at $13,16$.

${ }^{283}$ NISBETT \& Ross, supra note 239, at 52.

${ }^{284}$ See Gold, supra note 181 , at 520 (noting that "[s]ome vivid evidence is highly probative, making its impact on the jury's decisionmaking roughly commensurate with its objective probative value"). 
that situation arises, the availability heuristic will cause cognitive overreliance upon that piece of evidence and will cause unfair prejudice to occur, because the jury will rely disproportionately on the vivid piece of evidence. This is precisely the form of inferential error jurors commit when they view videotaped reenactments. ${ }^{285}$

\section{E. The Vividness of Videotape and Television}

In order to draw the conclusion that videotaped reenactments cause inferential error, it must first be established that the viewing of videotapes does in fact cause vividness and enhanced availability in the inferential process. The conclusion that individuals receive information more effectively from visualizations than they do from oral presentations may seem axiomatic, but psychologists and legal practitioners frequently advance the practical usefulness of this conclusion. ${ }^{286}$ In fact, the vividness of visual presentations has led one communications expert to conclude that the use of visual aids in the courtroom is tantamount to "creating a representative . . . to send back with [the jury] into the jury room. ${ }^{287}$

\section{Sight}

Individuals and jurors enhance their capability to perceive and learn through the use of sight. Information received via sight has a profound impact upon individuals:

From childhood, we first begin observing our parents and peers as models of behavior. The enormous amounts of information presented in our education process are absorbed primarily through sight. Our reasoning and imagination are fueled by information gathered with ... sight. Advertisers ... fiercely compete for our attention [and] [c]onsumer buying decisions for major items ... are tremendously influenced by visual impact as evidenced by the investment in advertising as well as product design. ${ }^{288}$

285 The Lopez and Hopperstad courts adverted to this type of cognitive overvaluing in excluding the reenactments from jury view. See supra parts II.B.2., II.B.3.a.

${ }^{286}$ See infra parts III.E.1-2.

${ }^{287}$ SONYA HAMLIN, WHAT MAKES JURIES LISTEN 383 (1985).

${ }^{288}$ Symposium Panel Discussion, Communicating with Juries: Demonstration and Discussion of Technological Advances in the Courtroom, 68 IND. L.J. 1081, 1082 (1993). 
Far more learning occurs via sight than through any of the other senses. ${ }^{289}$ This reality has led to the conclusion that "[i]f a lawyer keeps in mind that [the great majority] of what [jurors] learn will be through their eyes, he can be sure the jury will learn and remember the facts as he wishes them remembered and render their verdict accordingly. ${ }^{290}$ Practitioners are well aware of the benefits of using visual presentations and are frequently advised to "show the jury" in addition to telling them. ${ }^{291}$ Oral testimony is not the primary source of information retained by jurors; visual presentations account for the vast majority of retained information. ${ }^{292}$

${ }^{289}$ A comparison of learning through the five senses reveals that sight accounts for approximately $85 \%$ of all learning, while hearing only accounts for $10 \%$. Touch, taste, and smell each account for less than $2 \%$. See William C. Costopoulos, Persuasion in the Courtroom, 10 DUQ. L. REV. 384, 406 (1972).

${ }^{290} \mathrm{Id}$. at 406-07.

${ }^{291}$ See Hon. Charles L. Hardy, Helping Jurors Comprehend and Remember the Evidence, in THE JURY 1987: TECHNIQUES FOR THE TRIAL LAWYER, at 467, 472-74 (PLI Litig. \& Admin. Practice Course Handbook Series No. 340, 1987) (outlining demonstrative techniques for lawyers to assist the jury in understanding and remembering the evidence); Robert Seltzer, Effective Communication: Seeing is Believing, in Product LIABILITY OF MANUFACTURERS 1988: PREVENTION AND DEFENSE, at 597, 597 (PLI Litig. \& Admin. Practice Course Handbook Series No. 361, 1988) (advocating the use of visual presentations to communicate more effectively to jurors); Peter Perlman, Seeing is Believing: Making Proof More Meaningful, TRIAL, June 1981 at 34, 34 (advocating the use of videotape by trial lawyers); Windle Turley, Effective Use of Demonstrative Evidence: Capturing Attention and Clarifying Issues, TRIAL, Sept. 1989, at 62, 62 ("Primary challenges for trial lawyers are organizing facts and presenting them persuasively. Today, lawyers can rely on visual aids to help them meet these challenges effectively."); see also supra part I.C.

${ }^{292}$ One study measured juror retention of information presented in various forms and at different times.

Method of Presentation Retention Level (\%)
Telling

Showing

Telling and Showing

\begin{tabular}{cc}
\multicolumn{2}{c}{ Retention Level (\%) } \\
After 3 Hours & After 72 Hours \\
$70 \%$ & $10 \%$ \\
$72 \%$ & $20 \%$ \\
$85 \%$ & $65 \%$
\end{tabular}

The results of this study suggest that jurors retain purely visual information $100 \%$ better than purely oral testimony. Similarly, when oral and visual presentations are combined, jurors retain $650 \%$ more information than when presented with purely oral testimony. See Savage, supra note 45, at 440 n.32 (quoting Weiss-McGrath Report prepared by McGraw-Hill); see also HAMLIN, supra note 83, at 14 ("Human tellers corroborate and embellish but are no longer the major source of information."). 


\section{Seeing Television and Video ${ }^{293}$}

Individuals enhance their learning dramatically through the use of sight, and the visual media providing individuals with the most cognitive information are television and videotape. Learning still occurs through means other than sight, but " $[w]$ ords are no longer the primary message givers [as n]ow it is pictures that tell. ${ }^{n 294}$ By the time the average student completes high school, she will have spent more hours watching television than sitting in the classroom. ${ }^{295}$ Almost every American household contains a television set and the average television set is turned on for almost seven hours per day. ${ }^{296}$ Arguably, television "has become the primary common source of socialization and everyday information, ${ }^{n 297}$ and the media's major social function is to "influence the receiver's cognitions, attitudes, or behavior in some desired direction. ${ }^{n 298}$ Anthony and Vinson conclude, almost as a matter of fact, that " $[t]$ elevision, of course, is the primary source of visual learning and information." 299

Seeing a piece of evidence dramatically increases the likelihood that it will be remembered and subsequently made available for use in the decision-making process. ${ }^{300}$ Television and videotape, because of their prevalence and acceptance as a form of receiving relevant information, enhance the effects that sight has upon mental

${ }^{293}$ The purpose of this Section is not to discuss the effects of television on learning, but merely to point out that the viewing of television and video is vivid and attractive, thus illustrating that we as individuals have been taught to turn to television as a source of information produced in the form of attractive images and vivid pictures.

${ }^{294}$ HAMLIN, supra note 83, at 14 .

295 It is estimated that by the end of high school, the average student has watched over 15,000 hours of television and spent 11,000 hours in the classroom. See Anthony \& Vinson, supra note 282, at 13. Another researcher has concluded that the average American watches more than three hours of television per day and that the television set itself is on for an average of over six hours per day. As a result, if a child began watching television at the age of six, by the time she reaches age sixteen, she could conceivably have watched 20,000 hours of television. See D.W. RAJECKI, ATTITUDES 391 (1990).

${ }^{296}$ See George Comstock et al., Television and Human Behavior 85, 88 (1978).

${ }^{297}$ George Gerbner et al., Living With Television: The Dynamics of the Cultivation Process, in PERSPECTIVES ON MEDIA EFfects 17, 18 Jennings Bryant \& Dolf Zillman eds., 1986).

${ }^{298}$ RAJECKI, supra note 295, at 392 (citation omitted).

${ }^{299}$ Anthony \& Vinson, supra note 282, at 13.

${ }^{300}$ See supra part III.E.1. 
recognition and retention. ${ }^{301}$ Thus, it can be concluded that when an individual or a juror views videotaped material, that material is in fact vivid, resulting in enhanced availability in the inferential process and potential overvaluation in decision-making.

\section{F. Videotaped Reenactments and Unfair Prejudice-Applying the Heuristics}

Under this analysis of the Federal Rules of Evidence, unfair prejudice occurs when inferential error is committed. ${ }^{302}$ Inferential error arises when jurors improperly rely on certain cognitive processes to reach a decision. When these processes are relied upon, jurors may incorrectly infer generalizations concerning a large body of data from an unrepresentative sample ${ }^{303}$ or select the most mentally available data ${ }^{304}$ in order to make a decision. The use of the videotaped reenactment in criminal trials by the prosecution unfairly implicates jurors' use of both the representative heuristic and the availability heuristic as a result of both the content of the reenactment and the manner in which it is presented.

\section{The Representative Heuristic and the Videotaped}

Reenactment

Criminal trials, with the life and liberty of the defendants at stake, can be long, drawn-out affairs, lasting anywhere from several hours to several weeks. ${ }^{305}$ During the course of the criminal trial, jurors are presented with volumes of information-witness testimony, expert testimony, instructions from the bench, and arguments from counsel. ${ }^{306}$ Although one seminal study suggests that jurors generally understand the facts of the matter and correctly perceive

${ }^{\text {sol }}$ See supra notes 294-99 and accompanying text.

${ }^{302}$ See supra part III.C.3.

${ }^{303}$ See supra part III.D.I

${ }^{304}$ See supra part III.D.2.

${ }^{305}$ The trial of the four men accused in the terrorist attack on the World Trade Center began in October 1993 and the jury did not return guilty verdicts until March 4, 1994. See Richard Bernstein, 4 Are Convicted in Bombing at the World Trade Center that Killed 6, Stunned U.S., N.Y. TIMES, March 5, 1994, at A1.

${ }^{306}$ For example, in the World Trade Center bombing trial, "[t]he prosecution based its case on circumstantial evidence ... presented in 1,003 exhibits and the testimony of 206 witnesses, with the help of more than a dozen federal and state agencies." Sherrie F. Nachman, 1,003 Exhibits, 206 Witnesses, and One Major Victory, AM. LAw., May 1994, at 36, 36. 
the issues, ${ }^{307}$ courts have recognized that the use of the representative heuristic will cause jurors to ignore larger bodies of evidence in favor of more individual pieces of vivid, anecdotal evidence. ${ }^{308}$

Nowhere in a criminal trial is the potential greater for the misapplication of the representative heuristic than with the use of a videotaped reenactment. When presented with the reenactment, jurors, though frequently told that the reenactment is only the prosecution's version of the events, ${ }^{309}$ are tendered, in graphic, image-provoking form, a capsule summary of how the events of the case transpired. The disputed issues of the litigation are presented on television for the jurors to view. In New Jersey $v$. Spath, ${ }^{310}$ the reenactment would have illustrated the prosecution's version of how the victim was situated when struck by the bullet. In People $v$. Mitchell, ${ }^{311}$ the reenactment presented the prosecution's version of how the events occurred in Artie Mitchell's house on the night he was murdered. The court in Lopez $v$. State ${ }^{312}$ cautioned against this danger of misapplication when it commented that "whether intended or not [a reenactment] may sway a juror who has listened

${ }^{307}$ See HARRY KALVEN, JR. \& HANS ZEISEL, THE AMERICAN JURY 149 (1966).

${ }^{308}$ See, e.g., United States v. Ebens, 800 F.2d 1422, 1432-36 (6th Cir. 1986) (unfair prejudice occurred in admitting testimony that defendant made racist remarks eight years earlier in a prosecution for civil rights violations); LeSueur Creamery, Inc. v. Haskon, Inc. 660 F.2d 342, 351-52 (8th Cir. 1981) (excluding tax returns where they may have otherwise confused the jury in determining overall profits), cert. denied, 455 U.S. 1019 (1982); United States v. Green, 648 F.2d 587, 595 (9th Cir. 1981) (admission of pictures of firearms found at defendant's residence was prejudicial error in a criminal trial even though the pictures were used for the limited purpose of refuting the testimony of a codefendant); see also Gold, supra note 181, at $515 \mathrm{n} .78$ (citing other cases presenting this issue).

${ }^{309}$ The effectiveness of the judicial "limiting instruction" has been sharply questioned. Wissler and Saks have concluded that in a situation where a defendant's prior criminal convictions are admitted for the limited purpose of impeaching credibility, the trial judge's limiting instructions to the jury to evaluate the prior convictions solely for impeachment purposes will not counteract juror bias. The admission of the convictions triggers the intuitive juror belief that, "once a criminal, always a criminal," subsequently leading to a higher rate of convictions. See Roselle L. Wissler \& Michael J. Saks, On the Inefficacy of Limiting Instructions: When Jurors Use Prior Conviction Evidence to Decide on Guilt, 9 LAw \& HuM. BEHAV. 37,38 (1985). Thus, applying the Wissler and Saks conclusion to this situation, it appears likely that jurors would give little cognitive regard to a cautionary instruction from the bench requiring consideration of the reenactment as only the prosecution's opinion of how the events transpired.

${ }^{310}$ No. SGJ263908 (N.J. Super. Ct. Crim. Div. filed Dec. 5, 1990). For a further discussion of the Spath trial, see supra part II.B.4.b.

${ }^{311}$ No. 12462 (Cal. Super. Ct. Marin County indictment filed Sept. 17, 1991); for a further discussion of the Mitchell trial, see supra part II.B.4.a.

${ }^{312} 651$ S.W.2d 413 (Tex. Ct. App. 1983). 
to lengthy testimony. ${ }^{\text {313 }}$

The prejudice that occurs as a result of the use of the representative heuristic can be analogized to the purchase of the Toyota by the durability- and longevity-conscious consumer. ${ }^{314}$ The consumer, prior to deciding on the purchase of a Toyota, examined a large body of relevant evidence in the form of user surveys and maintenance analyses and arrived at a preliminary decision based on the results of that evidence. Likewise, in the courtroom, jurors are presented with numerous witnesses; exhibits, and arguments by both sides in order to have the relevant data available to make a determination of guilty or not guilty. Yet in light of all of the pallid, relevant data presented to the consumer pertaining to the durability and longevity of the Toyota, the consumer's choice was swayed by a small amount of relevant, yet extremely vivid, contradictory evidence. In the courtroom, the videotaped reenactment-one short, vivid summation of all the events argued and contested throughout the course of the trial-has the same impact on juries as does the dissatisfied Toyota customer on the potential purchaser.

The reenactment, as a result of the representative heuristic, will likely overshadow the majority of the probative testimonial evidence that has been presented and will improperly serve as the basis for a decision. Inferential error is therefore committed, and unfair prejudice according to Rule 403 will occur, as the reenactment distracts attention from relevant evidence that is more representative of the whole body of evidence. The Lopez court, without the benefit of an in-depth psychological analysis, used its judicial instincts to determine the dangers accompanying the reenactment due to juror overreliance on the representative heuristic and properly excluded its use in future trials. ${ }^{315}$

2. The Availability Heuristic and the Videotaped Reenactment

Any time an individual makes a decision, the information that is drawn upon for use in the cognitive processes has been acquired from an external source. Once acquired, that information must subsequently be recalled for use in decision-making. Which information is most readily available to be used in rational decisionmaking? The information that is most available for decision-making

${ }^{313}$ Id. at 415; see also supra part II.B.2.

${ }^{314}$ See supra note 256 and accompanying text.

${ }^{315}$ See supra part II.B.2. 
is that which impacts in some personal way-whether it impacts emotionally or provokes images which are imprinted on the mental battlefield.

Even more so than the representative heuristic, ${ }^{316}$ reliance on the availability heuristic to select the information used during juror decision-making has the potential to create inferential error and, therefore, unfair prejudice against the defendant. This potential is particularly relevant to a situation involving the use of a videotaped reenactment. The heuristic dictates that the data which is cognitively most available, or for the purpose of this analysis, cognitively vivid, will be thrust to the mental forefront and be given primary consideration in the decision-making process. ${ }^{317}$ Yet cognitive availability or vividness is not necessarily tied to probative value, and inferential error will be created when the vivid evidence is improperly relied upon for decision-making. ${ }^{318}$

Not all vivid evidence's probative value is substantially outweighed by unfair prejudice. ${ }^{319}$ Certain demonstrative evidence can have probative value commensurate with its potential cognitive availability. The presentation of the gun used to commit a murder can have a potent mental impact upon the jury and can provide mental imagery unmatched by any oral testimony. While deliberating, the jury will readily recall the heavy, icy, dark object that was used to end a human life. Yet the gun, as it has been directly linked to the crime, is highly probative, and its use during juror deliberations provides insight into the actual circumstances of the crime.

The viewing of the videotaped reenactment by the jury presents a prime example of the potential for inferential error created by the use of the availability heuristic. The reenactment has no independent probative value or link to the case, because it is demonstrative evidence that is purely illustrative in nature. ${ }^{320}$ Its function is derivative, in that it is a post-event creation, prepared exclusively for trial. Thus, the videotaped reenactment's evidentiary value differs greatly from that of the authenticated murder weapon, which carries

${ }^{316}$ See supra part III.F.1.

${ }^{317}$ See supra notes 259-65 and accompanying text.

${ }^{318}$ The Hopperstad court alluded to the potential impact of the availability heuristic in holding that the viewing of the reenactment, presented exactly as the prosecution's witnesses testified, "is bound to affect the jury out of all proportion to its value as evidence." State v. Hopperstad, 367 N.W.2d 546, 549 (Minn. Ct. App. 1985); see also supra notes $241-44$ and accompanying text.

${ }^{319}$ See supra part III.C.1. (discussing the Rule 403 balancing test).

${ }^{320}$ See supra part I.A. 
its own independent probative value. The reenactment can only be presented in conjunction with the testimony of a witness.

In re-creating the events surrounding a plane crash in a civil trial, ${ }^{321}$ an expert may use objective data taken from the flight recorder, information gathered from the flight tower, and testimony of eye witnesses. She then may apply the laws of engineering or physics to determine the fate of an aircraft by reconstructing the actual details of its demise. In a criminal trial, the reenactment of the crime scene is generally speculative and is created without the defendant's help. ${ }^{32}$ The prosecution develops a theory based upon witness testimony, ballistic reports, or the circumstances of the case, and then attempts to re-create the event in order to present it to the jury. In the Mitchell trial, the reenactment presented to the jury was the product of prosecutorial speculation based upon the forensic evidence gathered from the crime scene. ${ }^{323}$ No eyewitnesses were present during the commission of the crime, other than the defendant. ${ }^{324}$ The reenactment is essentially a summation, a compilation of all the witnesses who have testified for the prosecution-a compilation that is packaged into a neat, made-for-television movie-a movie with no factual value in and of itself. ${ }^{325}$

The danger of unfair prejudice presented by the videotaped reenactment is a function of both the manner of the presentation and the content of the presentation. That danger is only accentuated by its stark lack of probative value. The availability heuristic suggests that the reenactment will be readily recalled and heavily relied upon during the decision-making process. Individuals learn more readily through sight, and a key component of the learning process comes

${ }^{321}$ See supra notes 57-70 and accompanying text.

${ }^{322}$ The participation of the defendant in creating the reenactment is not necessarily a guarantee for accuracy, as defendants are generally motivated by a desire to be acquitted. This desire functions in a similar manner to the prosecution's quest for a conviction. See, e.g., State v. Trahan, 543 So. 2d 984 (La. Ct. App. 1989) (upholding the exclusion of defendant's videotaped reconstruction as it conflicted with defendant's own version of the facts), overruled on other grounds by State v. Simpson, 551 So. 2d 1303, 1304 (La. 1989), but affd, 576 So. 2d 1 (1990).

${ }^{323}$ See supra part II.B.4.a.

${ }^{324}$ Even if the reenactment is premised upon the testimony of eyewitnesses, similar dangers continue to exist. The accuracy of eyewitness testimony has been the focus of much critical examination. See generally ELIZABETH F. LOFTUS \& JAMES M. Doyle, Eyewtrness Testimony: Civil and CRiminal (2d ed. 1992).

${ }^{325}$ The Hopperstad court also opined on the subject of the reenactment's probative value in characterizing the reenactment as irrelevant. State v. Hopperstad, 367 N.W.2d 546, 549 (Minn. Ct. App. 1985); see also supra notes 110-11 and accompanying text. 
through the use of the television, an everyday source of entertainment and information. ${ }^{326}$ A television videotape, much more than other forms of demonstrative visual evidence, leaves a lasting impression on juror's mental processes, since its vividness dictates that it will be readily available for cognitive recall. ${ }^{327}$ The videotaped reenactment, because of its mental impressionability, is exactly the type of vivid information to which the availability heuristic grants cognitive priority during decision-making.

The content of the reenactment serves to enhance its vividness, while at the same time increasing the likelihood of inferential error. As argued in the preceding section, the jury is being presented with a prepackaged video version of the contested issues. The reenactment does not assist in clarifying corollary issues, but is presented to be illustrative of the disputed issues-thus enhancing its memorability. The impact of seeing the crime committed on television in the manner depicted by the prosecution and its witnesses makes it more likely that the reenactment will "be accepted as representative of the ... events it describes [rather] than ... pallid evidence. ${ }^{n 28}$

The potential for inferential error presented by juror overreliance on the videotaped reenactment substantially outweighs its probative value. The Lopez court, again using its judicial instincts to assess the psychological landscape, touched upon all of the relevant cognitive issues, concluding that "any staged, re-enacted criminal acts ... involving human beings are impossible to duplicate in every minute detail and are therefore inherently dangerous, offer little in substance and the impact of the re-enactments is too highly prejudicial to insure ... the defendant a fair trial." 329

\section{CONCLUSION}

Change is not necessarily for the better. Before practitioners and courts rush headlong into the twenty-first century and usher the use of advanced computer and video technology into the hallowed halls of justice, ${ }^{330}$ they should take a moment to step back and

${ }^{326}$ See supra part III.E.

${ }^{327}$ See supra part III.D.2.c.

${ }^{328}$ Gold, supra note 181 , at 517.

${ }^{329}$ Lopez, 651 S.W.2d at 416. The courts in Hopperstad and Caudill also agreed that the prejudicial psychological impact of the videotaped reenactment outweighed its probative value. For a complete discussion of the rationales of these courts, see supra parts II.B.2., II.B.3.a., II.B.3.c.

${ }^{350}$ See supra part II.B.1. 
reflect upon the impact of this technology on the rights of the criminal defendant. In allowing the use of the videotaped reenactment during criminal trials, the Mitchell and Spath courts failed to properly consider the prejudicial impact that the reenactments would have upon the cognitive processes of the jury. The use of the videotaped reenactment, while assisting the prosecution in presenting its case and meeting its burden of proof, clearly creates the potential for inferential error and unfair prejudice as proscribed by Rule 403 of the Federal Rules of Evidence. Technology may be advancing at a rate unparalleled in judicial history, but that does not necessarily lead to the conclusion that fundamental protections created to safeguard the rights of criminal defendants must be left in its considerable wake. Jurors may not be able to prevent the cognitive overvaluing that occurs when viewing a videotaped reenactment, but courts adhering to the Federal Rules balancing test should recognize the deleterious effect the reenactment has upon juror deliberations and return it whence it came-the editing room of the litigation specialist. 


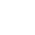

